Earth Surface Processes And Landforms

February 2017, Volume 42 Issue 2 Pages 272-289

http://dx.doi.org/10.1002/esp.3987

Achimer

http://archimer.ifremer.fr/doc/00380/49082/

(c) 2016 John Wiley \& Sons, Ltd.

\title{
Controls on Holocene denudation rates in mountainous environments under Mediterranean climate
}

\author{
Molliex S. ${ }^{1,2,{ }^{*}}$, Jouet Gwenael ${ }^{1}$, Freslon Nicolas ${ }^{1,3}$, Bourles D. L. ${ }^{3}$, Authemayou C. ${ }^{2}$, Moreau Julien ${ }^{1}$ \\ ${ }^{3}$, Rabineau Marina ${ }^{2}$ \\ ${ }^{1}$ IFREMER, Dept Geosci Marines, F-29280 Plouzane, France. \\ ${ }^{2}$ Univ Bretagne Occidentale, Inst Univ Europeen Mer, UMR CNRS 6538, Lab Domaines Ocean, F- \\ 29280 Plouzane, France. \\ ${ }_{3}^{3}$ Aix Marseille Univ, Coll France, CNRS, CEREGE,UM34,IRD, BP80, F-13545 Aix En Provence 4, \\ France. \\ * Corresponding author : S. Molliex, email address : smolliex@gmail.com
}

\begin{abstract}
:
The Mediterranean domain is characterized by a specific climate resulting from the close interplay between atmospheric and marine processes and strongly differentiated regional topographies. Corsica Island, a mountainous area located in the western part of the Mediterranean Sea is particularly suitable to quantify regional denudation rates in the framework of a source-to-sink approach. Indeed, fluvial sedimentation in East-Corsica margin is almost exclusively limited to its alluvial plain and offshore domain and its basement is mainly constituted of quartz-rich crystalline rocks allowing cosmogenic nuclide Be-10 measurements. In this paper, Holocene denudation rates of catchments from the eastern part of the island of Corsica are quantified relying on in situ produced Be-10 concentrations in stream sediments and interpreted in an approach including quantitative geomorphology, rock strength measurement (with a Schmidt Hammer) and vegetation cover distribution. Calculated denudation rates range from 15 to $95 \mathrm{~mm} \mathrm{ka}(-1)$. When compared with rates from similar geomorphic domains experiencing a different climate setting, such as the foreland of the northern European Alps, they appear quite low and temporally stable. At the first order, they better correlate with rock strength and vegetation cover than with morphometric indexes. Spatial distribution of the vegetation is controlled by morpho-climatic parameters including sun exposure and the direction of the main wet wind, so-called Libecciu'. This distribution, as well as the basement rock strength seems to play a significant role in the denudation distribution. We thus suggest that the landscape reached a geomorphic steady-state due to the specific Mediterranean climate and that Holocene denudation rates are mainly sustained by weathering processes, through the amount of regolith formation, rather than being transport-limited. Al/K measurements used as a proxy to infer present-day catchment-wide chemical weathering patterns might support this assumption.
\end{abstract}

Keywords: Be-10-derived denudation rates, Schmidt Hammer, Quaternary, quantitative geomorphology, weathering 
Relief is the result of the interactions between denudation and sedimentation that are mainly controlled by tectonic forces and climate changes (e.g., Davies et al., 1977; Molnar

47 and England, 1990; Allen, 1997; Willett et al., 2006; Whipple, 2009). The buildup of

48 topography by tectonics causes river channels and hill slopes to steepen, increasing relief 49 and, as a result, enhancing denudation rates and sediment flux (e.g., Willett, 1999; 50 Montgomery and Brandon, 2002). Moreover, rock fracturing induced by deformation 51 increases the likelihood of erosional transport (Molnar et al., 2007). On the other hand, a 52 change in climatic parameters will directly impact denudation efficiency and rates (e.g., 53 Whipple et al., 1999; Bonnet and Crave, 2003). Recent studies, both onshore and offshore, 54 also highlighted the role played by glaciation in the destabilization and denudation of 55 mountainous environments during the Quaternary (Hinderer, 2001; Norton et al., 2010; Jorry 56 et al., 2011; Glotzbach et al., 2013).

Millennial to present-day denudation rate estimates in recent orogens correlate with environmental and/or geomorphic metrics such as local relief, slope gradient, channel 59 steepness, mean annual precipitations, and percentage of glacier cover (e.g., Summerfield 60 and Hulton, 1994; Brandon et al., 1998; Montgomery and Brandon, 2002; DiBiase et al., 61 2010; Bermudez et al., 2013; Glotzbach et al., 2013). For long-term scales, relief evolves 62 independently of denudation processes toward steady-state equilibrium between denudation 63 rates and isostatic rock uplift (e.g., Willett and Brandon, 2002). On continental margins, long64 term sediment fluxes directly depend on the water discharge and hydrology of the 
contributing rivers (Litty et al., 2016), the latter being controlled by climate and drainage basin characteristics (catchment morphology, soil and vegetation developments, bedrock type) (Syvitski and Morehead; 1999).

Recently, numerous studies used ${ }^{10} \mathrm{Be}$-derived catchment-wide denudation rates to quantify feedbacks between tectonics, climate, denudation, and the resulting catchment morphometry in various different settings (e.g., Riebe et al., 2000; Matmon et al., 2003; Wittmann et al., 2007; Ouimet et al., 2009; Palumbo et al., 2009; DiBiase et al., 2010, 2012; Delunel et al., 2010; Henck et al., 2011; Roller et al., 2012; Savi et al., 2014). Denudation rates in mountainous settings have been shown to often be partly correlated to geomorphic metrics, relief and slope in particular (e.g. compilation in Montgomery and Brandon, 2002; Portenga and Bierman, 2011; Willenbring et al., 2013), but some studies highlight the importance of rock strength (Clapp et al., 2001; Morel et al., 2003; Palumbo et al., 2009) and/or bedding orientation (Chittenden et al., 2014; Cruz Nunes et al., 2015), vegetation cover (Roller et al., 2012; Torres Acosta et al., 2015), precipitation and discharge (Bookhagen and Strecker, 2012), and uplift rates (Wittmann et al., 2007; Baran et al., 2014; Godard et al., 2014).

The Mediterranean climate is determined by a close interplay between atmospheric and marine processes and strongly differentiated regional topographies (Xoplaki et al., 2004 ; Kulhemann et al., 2008). This leads to a specific subtropical climate with strong seasonal variability, relatively warm temperatures and highly fluctuating precipitations. Very few studies focused on catchment-wide denudation in such Mediterranean climate environment, despite that the encountered specific climatic conditions are able to efficiently model landscapes and create some impressive erosional features within granites such as "tafoni" (Brandmeier et al., 2011).

In this study, we investigate the denudation rates of the mountainous island of Corsica in the Mediterranean Sea, particularly focusing on catchments draining the northeastern part of the continental margin (the Golo River and surrounding watersheds). Holocene denudation rates are deduced from in-situ produced cosmogenic ${ }^{10} \mathrm{Be}$ concentration measurements from stream sediments. They are then compared to rock strength and environmental and geomorphic metrics derived from digital elevation models (DEM). Then, forcing parameters such as morphology, climate, uplift, rock strength, vegetation patterns, and catchment area are discussed.

\section{1- Geological setting:}


Northeastern Corsica is characterized by a steep mountainous morphology, with elevations reaching more than $2,700 \mathrm{~m}$ (Fig. 1). It is composed of two main structural units (Fig. 1): (i) the Hercynian unit, an underlying magmatic basement related to the late Paleozoic Hercynian Orogeny, constitutes the highest part of the island (up to $2704 \mathrm{~m}$ in Monte Cinto); (ii) the Alpine unit, an overthrusted nappe-unit built from Mesozoic oceanic crust and sedimentary series emplaced and metamorphosed during the so-called "Pyrenean" compression lasting from the Late Cretaceous to the Eocene (Mattauer et al., 1981; Gibbons and Horak, 1984; Harris, 1985; Fellin et al., 2006; Danisik et al., 2007). This Alpine unit was exhumed during an early to middle Miocene (Cavazza et al., 2001; Zarki-Jakni et al., 2004) regional extension, which occurred due to the Ligurian sea opening which itself was related to the extension in the back-arc area of the Apennines orogen (e.g., Jolivet et al., 1998). This caused the drifting of the Corsica-Sardinia block from the European continent of southern France to its current location (e.g. Réhault et al., 1984; Mauffret and Gorini, 1996; Roca et al., 1999; Gattacceca et al., 2007) and reactivated the contact between the Hercynian and Alpine units as a normal shear zone (Jolivet et al., 1991; Daniel et al., 1996; Brunet et al., 2000). Shallow water sediments were then deposited above the Alpine units in small Miocene basins (Orszag-Sperber and Pilot, 1976) during the early-middle Miocene (Ferrandini et al., 1998; Cubells et al., 1994). In the late Miocene-Pliocene, crustal extension in the proto-Tyrrhenian Sea resulted in the subsidence and deposition of continental and shallow marine deposits up to $2 \mathrm{~km}$-thick in numerous half-grabens (onshore and offshore), as in the Aleria basin (Fournier et al., 1991; Loÿe-Pilot et al., 2004). Since the late Miocene, no major tectonic events have affected Corsica. However, transpressive faulting within the late Miocene to Quaternary units suggest that far-field compressional stresses still affect northeastern Corsica to the present-day (Fellin et al., 2005a; Serrano et al., 2013).

The evolution of paleo-surfaces exposed at high altitudes in Corsica has been investigated using apatite fission-track and cosmogenic nuclide methods (Kuhlemann et al., $2007 ; 2009)$. These studies suggest that the central and northernmost parts of Corsica have experienced continuous exhumation since the Miocene, with high denudation rates in the order of $1000-1500 \mathrm{~mm} \cdot \mathrm{ka}^{-1}$ in the early-middle Miocene decreasing to less than $200 \mathrm{~mm} \cdot \mathrm{ka}^{-}$ 1 from the late Miocene to the present-day (Fellin et al. 2005a; Kuhlemann et al., 2007; 2009). This leads to the local preservation of old (Paleocene-Eocene) remnant planation surfaces (Kuhlemann et al., 2005a; Danisik et al., 2012). Quaternary uplift rates were investigated using elevated marine terraces and stair-cased alluvial terrace geometry (Conchon, 1978; 1999; Collina-Girard, 1999; Fellin et al., 2005b; Kuhlemann et al., 2005b). These rates range between $50 \mathrm{~mm} \cdot \mathrm{ka}^{-1}$ along the southwestern coast, $150-300 \mathrm{~mm} \cdot \mathrm{ka}^{-1}$ on the northwestern coast and 200-400 mm. ka ${ }^{-1}$ in the northeastern part. However, large 
uncertainties are associated to these rates due to the fact that some terraces used in these studies are not well dated and accurate corresponding sea-levels are difficult to estimate. Moreover, recent uplift rates are also expected to vary significantly between different tectonic regimes across the island (Lenôtre et al., 1996). Nevertheless, while recent deformation is well-documented near coastal domains and eastern alluvial plains (e.g. Serrano et al., 2013), the lack of significant seismicity, as well as the lack of recent deformation evidence in upstream areas, leads us to consider Corsica to be a tectonically stable domain.

With a catchment area of $1,214 \mathrm{~km}^{2}$ and a length of $89 \mathrm{~km}$, the Golo River is the largest river in Corsica (Fig. 1). It passes through the Alpine and Hercynian domains. Its average gradient is $30 \mathrm{~m} / \mathrm{km}$. Preservation of fluvial terraces is low due to the very steep and confined nature of the valleys. Despite the relatively steep slopes, there is no evidence of recent landslides, as the colluvial fans are covered by dense vegetation (Sømme et al., 2011). Its main tributaries are the Asco $\left(34.1 \mathrm{~km} ; 165 \mathrm{~km}^{2}\right)$, Tartagine $\left(30.2 \mathrm{~km} ; 136 \mathrm{~km}^{2}\right)$, Casaluna $(25.3$ $\mathrm{km} ; 100 \mathrm{~km}^{2}$ ), and Lagani rivers (22.1 km; $47 \mathrm{~km}^{2}$ ) (Fig.1). Downstream, the Golo alluvial plain (Marana plain; Fig.1) is only $11 \mathrm{~km}$ wide. Deposits on this plain are mainly constituted by pebbles in a sandy matrix and are not exclusively provided by the Golo catchment, but also by two coastal catchments draining only the Alpine domain, the Bevinco to the north and Fium Alto to the south (Fig.1). Corsica is experiencing a subtropical Mediterranean climate with strong seasonal variability. The mean annual temperatures are relatively warm $\left(15.9^{\circ} \mathrm{C}\right.$ on the Marana plain), and the precipitations are highly spatially variable, ranging from 700 mm. $\mathrm{yr}^{-1}$ on the Marana plain to $1300-1400 \mathrm{~mm} . \mathrm{yr}^{-1}$ in the highest parts of the Golo catchment (Kuhlemann et al., 2007; Sømme et al., 2011). Strong seasonal variations in precipitation result in high flood discharge from the Golo River, with an average discharge of $20.4 \mathrm{~m}^{3} . \mathrm{s}^{-1}$ and a flood peak reaching up to $734 \mathrm{~m}^{3} \cdot \mathrm{s}^{-1}$ (HYDRO French Database, www.hydro.eaufrance.fr). Vegetation is dominated by evergreen bushes and trees in the lowlands with increasing amounts of deciduous and pine forest at higher elevations (Reille et al., 1997; 1999). There is no recent glacier permanent ice in the studied area (Wilhelm, 1975), but the uppermost part of the Golo watershed was glaciated during the Last Glacial Maximum (LGM) and subsequent glacial phases (Klaer, 1956; Kuhlemann et al., 2008; Krumrei, 2009).

\section{2- Material and methods}

\section{2-1) Morphometric parameters calculations}

For each catchment, morphometric parameters including mean elevation, mean slope, shape factor, sinuosity, hypsometric integral, local relief, and the normalized 
steepness index (Ksn) (Tab. 1), were computed from a 25 m-resolution DEM provided by the French Geographical Institut (IGN).

Mean elevation and mean slope were computed by calculating the average value of each pixel of the DEM and slope map (derivative DEM), respectively. The shape factor corresponds to the ratio between maximum width and perpendicular maximum length of the catchment. The sinuosity is the ratio between the straight distance from the source to the outlet and the same distance along the stream.

The hypsometric integral $(\mathrm{Hi})$ is a non-dimensional parameter representing, after normalization, the repartition of the drainage area as a function of the elevation of the main catchment stream (Strahler, 1952). The shape of the hypsometric curve as well as the value of $\mathrm{Hi}$ express the volume of a basin that has not yet been eroded and thus aim to quantitatively express the evolution of a catchment (Strahler, 1952). A convex hypsometric curve with a high integral value $(>0.6)$ characterizes a weakly eroded catchment, while a concave hypsometric curve with a low integral value $(<0.4)$ characterizes a strongly eroded catchment. This parameter is highly dependent on the erodibility of the rocks (Hurtrez and Lucazeau, 1999) and on the size of the catchment (Hurtrez et al., 1999; Walcott and Summerfield, 2008).

The local relief is defined as the difference in elevation between the interfluve and the lowest point in the erosive channel (Ahnert, 1984). It therefore characterizes the incision, the relief is high if incision is strong (e.g. ; Champagnac et al., 2014). The geophysical relief is another more convenient parameter, calculated as the difference between a smooth surface connecting the highest points in the current landscape and the current topography (Small and Anderson, 1998; Brocklehurst and Whipple, 2002). This smooth surface was created by computed a flow accumulation grid from an inverse DEM. Indeed, the high values of flow accumulation computed from an inverse DEM correspond to the main interfluves and highpoints. The value of geophysical relief obtained by this method highly depends on the "tension" of the smooth surface, i.e. the number of the high points chosen (Ahnert, 1984; Lucazeau and Hurtrez, 1997; Champagnac et al., 2012). For our calculation, we created two smooth surfaces with different "tension" using two border values for flow accumulation (over 1000 cells and over 2000 cells) that correspond to the range of representative values.

A hydrographic network has a particular relationship between its slope and its drainage area (Hack, 1957; Flint, 1974; Howard and Kerby, 1983), which can be written as the slope-drainage area relationship:

$$
S=k s . A^{-\theta}
$$


where $S$ is the slope, $A$ is the drainage area, and $k s$ and $\theta$ are the steepness and the concavity of the studied stream, respectively. The concavity $\theta$ depends on erosional processes and can be related to orographic rain (Schlunegger et al., 2011) and denudation rates (Vanacker et al., 2015), whereas the steepness index $k s$ depends on erodability and rock uplift. (Howard et al., 1994; Willgose, 1994; Whipple and Tucker, 1999). Since these two parameters are independent, it is possible to normalize ks using the same reference concavity for all watersheds (Snyder et al., 2000; Whipple, 2004; Duvall et al., 2004). This new parameter $(k s n)$ is often used to account for rock uplift in geomorphological studies (e.g. Wobus et al., 2006; Kirby and Whipple, 2012). In this study, using a reference concavity of 0.5 , we calculated $\mathrm{ksn}$ for each $1 \mathrm{~km}$-long stream section in the studied area as well as a weighted average $k s n$ for each catchment.

To compute the vegetation cover pattern, we used the "Corine Land Cover" European program database (French data downloadable on http://www.statistiques.developpementdurable.gouv.fr/donnees-ligne/li/1825.html).

\section{2-2) In-situ produced ${ }^{10} \mathrm{Be}$ concentrations and estimations of millennial-scale denudation rates}

Rocks exposed to cosmic rays accumulate cosmogenic nuclides whose concentrations depend on their production rates $(P)$, their half-lives, and the denudation rates (e.g. Gosse and Philips, 2001; Dunai, 2010). With long enough exposure to cosmic ray derived particles, cosmogenic nuclide concentrations reach a steady-state equilibrium at which cosmogenic nuclide gain due to production equals losses due to denudation and radioactive decay (e.g. von Blanckenburg, 2005). At the catchment area scale $(A)$, gain due to production is $(P \times A)$, while losses can be estimated by the mean concentration within river sediment grains at the outlet $(C)$ multiplied by the sediment flux $(F)$. The concentration of a particular cosmogenic nuclide $\left({ }^{10} \mathrm{Be}\right)$ measured in sediments sampled from river outlets enables us to estimate the sediment flux (and therefore the denudation rate) at the catchment scale, assuming constant erosion in the catchment (Brown et al., 1995; Bierman and Steig, 1996; Granger et al., 1996). The integration time scale is equal to the absorption depth scale ( $\sim 60 \mathrm{~cm}$ in silicate rock; Lal, 1991) divided by the denudation rate. It often corresponds to the last hundreds or thousands of years, depending on the denudation rate.

Sixteen samples from active riverbed sands were collected during fieldwork in 2012 at the outlet of sub-catchments from the Golo watershed and surrounding areas in order to determine their mean denudation rate from their in-situ produced ${ }^{10} \mathrm{Be}$ concentrations (Fig. 3; Tab. 2). The physico-chemical preparation of the samples and the AMS measurements of their ${ }^{10} \mathrm{Be}$ concentrations were carried out at the Laboratoire National des Nucléides 
237 Cosmogéniques (LN2C) in the Centre Européen de Recherche et d'Enseignement des 238 Géosciences de l'Environnement (CEREGE), in Aix-en-Provence. Samples were prepared for ${ }^{10} \mathrm{Be}$ isotopic measurements following chemical procedures modified from Brown et al. (1991), Kohl and Nishiizumi (1992), and Merchel and Herpers (1999). For all samples, sands were sieved to isolate the $250-1000 \mu \mathrm{m}$ fraction. The magnetic fraction was removed with a magnetic separator (Frantz-type), and pure quartz was obtained by at least 3 repeated $10 \% \mathrm{H}_{2} \mathrm{SiF}_{6}-\mathrm{HCl}$ etchings and 3 repeated $\sim 3 \% \mathrm{HNO}_{3}-\mathrm{HF}$ etchings. Atmospheric ${ }^{10} \mathrm{Be}$ was subsequently eliminated by 3 sequential dissolutions with diluted HF. Approximately $300 \mu \mathrm{g}$ of an in-house ${ }^{9} \mathrm{Be}$ carrier solution, prepared from deep-mined phenakite (Merchel et al., 2008), was added to each sample, and residual grains were dissolved in a strong HF solution. After the obtained solutions were evaporated to dryness and the residues were dissolved in hydrochloric acid, Be was separated by anion and cation exchange columns. After the solution volumes were reduced by heating, the Be hydroxides precipitated using $\mathrm{NH}_{3 \mathrm{aq}}$ were dried and finally ignited at $900^{\circ} \mathrm{C}$ to $\mathrm{BeO}$. BeO targets were prepared for measurement at the French National Accelerator Mass Spectrometry facility (ASTER), in CEREGE, Aix-en-Provence. The obtained ${ }^{10} \mathrm{Be} /{ }^{9} \mathrm{Be}$ ratios were corrected for procedural blanks and calibrated against the National Institute of Standards and Technology standard reference material 4325 by using an assigned value of $2.79 \pm 0.03 \times 10^{-11}$ and $\mathrm{a}^{10} \mathrm{Be}$ half-life of $1.387 \pm 0.012 \times 10^{6}$ years (Korschinek et al., 2010; Chmeleff et al., 2010). Analytical uncertainties (reported as $1 \sigma$ ) include uncertainties associated with AMS counting statistics, chemical blank measurements, and AMS internal error (0.5\%). Long-term AMS measurements of procedural blanks yield a background ratio of $3.0 \pm 1.5 \times 10^{-15}$ for ${ }^{10} \mathrm{Be} /{ }^{9} \mathrm{Be}$ (Arnold et al., 2010). A sea-level high-latitude (SLHL) spallation production of $4.03 \pm 0.18$ at $\mathrm{g}^{-1} \mathrm{yr}^{-1}$ (weighted mean of the most recently calibrated production rates in the Northern Hemisphere; see Molliex et al., (2013) for references) was used and scaled for latitude (Stone, 2000) and elevation. The production rate is calculated for each cell of the DEM constituting the catchment, and the mean catchment production rate value is calculated by averaging the values of quartz-producing rock areas following the method described by Delunel et al., (2010) and using Balco's (2001) script to calculate the shielding factor. The contribution of muons to the production rate was calculated using the physical parameters evaluated by Braucher et al. (2011).

The presence of glaciers in some catchments during the integration time violates the steady state assumption inherent in this method, which aims to determine a catchment-wide denudation rate using in-situ produced ${ }^{10} \mathrm{Be}$ (Brown et al., 1995; Bierman and Steig, 1996; Granger et al., 1996), and may lead to an overestimation of the denudation rates (Gosse and Philips, 2001; Vance et al., 2003; Portenga et al., 2015). Regarding the samples we 
analyzed, the integration times may cover different glacial periods: LGM from 23 to $19 \mathrm{ka}$ (Mix et al., 2001); Older Dryas (OD) from 17 to 14.7 ka (Severinghaus et al., 1998; Stanford et al., 2006), and Younger Dryas (YD) from 12.9 to $12.1 \mathrm{ka}$ (Cacho et al., 2002). We therefore used a map of glacier coverage, produced by Krumrei (2009), for each climatic period to determine the part of the studied catchments' surface affected by the presence of glaciers.

Among the selected catchments, there are sub-catchments nested in "parent" basins. In order to avoid biases in statistical analysis because of possible dependency between parent and nested catchments, effective denudation rates for the non-nested portion outside of the nested sub-catchment were computed following the methods of Granger et al., (1996) and Portenga et al., (2015): Effective denudation rate $=\frac{\text { Parent basin sediment flux }- \text { Sub basin sediment flux }}{\text { Parent basin area }- \text { Sub basin area }}$

The sediment flux being defined as:

Sediment flux $={ }^{10}$ Be denudation rate $\times$ Catchment area

\section{2-3) Quantification of rock strength by Schmidt Hammer in-situ measurements}

Variations in rock competence play an important role in determining bedrock incision and denudation rates (e.g. Hack, 1957; Stock and Montgomery, 1999; Whipple et al., 2000; Sklar and Dietrich, 2001; Duvall et al., 2004). The rebound values (Q) given by Schmidt Hammer measurements are more widely used to quantify rock competence in geomorphologic studies (e.g. Duvall et al., 2004; Goudie, 2006; Engel et al., 2014). The Q value appears at a first order to be a good indicator of the resistance of rocks to erosion and is now extensively used in geomorphic studies, even if some other factors, however difficult to infer at this scale, such as fracturing density or chemical composition, enhance erodability. The details of the operational aspects of the Schmidt Hammer method can be found in Basu and Aydin (2004) and Aydin and Basu, (2005). In order to assess variations in bedrock competence, 143 fresh outcrops in 31 different lithologic units in the Golo catchment were used to measure rock strength and define a mean and mode rebound value $(Q)$ for each type of rock. For each site, 15 individual measurements on non-fractured and non-weathered rock surfaces were collected, omitting any test that yielded a hollow sounding impact, that fractured the rock, or that yielded a rebound value $(Q)<30$ since the minimum instrument reading is 30 . Unconsolidated rocks such as marls or alluvial deposits were thus not tested, 
but these rocks only represent less than $5 \%$ of the total Golo drainage area. A mean value was then applied to each lithologic unit in order to create a map of the rock strength of the Golo catchment. This map was used to estimate the catchment-averaged rebound value by computing the weighted mean of each lithologic unit relative to its extension in the catchment.

\section{2-4) Inferring wheathering intensity from $\mathrm{Al} / \mathrm{K}$ concentration}

The chemical erosion of silicates (i.e. weathering) is defined by the alteration of $\mathrm{K}$ feldspath to kaolinite. The clay mineralogy of a sediment can be inferred from the analysis of two major elements ( $\mathrm{Al}$ and $\mathrm{K}$ ) which characterize the weathering degree of clays. $\mathrm{A}$ high $\mathrm{Al} / \mathrm{K}$ ratio reflects a high abundance of kaolinite and thus a high weathering degree (e.g. Schneider et al., 1997). Measurements of the Al/K ratio were performed on the $<45 \mu \mathrm{m}$ fraction of 26 river sediment samples. Corsican riverbed sediments are typically characterized by coarse grains and contain very little clay material due to the rapid transport of fine particles. Thus, the clay samples collected for $\mathrm{Al} / \mathrm{K}$ measurements are from small natural dams where fine particle sedimentation can occur. At each sampling site, a large amount of sediment was sieved using one liter of river water and then only the 0-125 $\mu \mathrm{m}$ fraction was transferred to a pre-cleaned polypropylene bottle. Water was then discarded by centrifugation at the laboratory and the sediment was sieved at $45 \mu \mathrm{m}$. The 125-45 $\mu \mathrm{m}$ fraction was discarded and the fine fraction $(<45 \mu \mathrm{m})$ was dried for 12 hours at $90^{\circ} \mathrm{C}$ and crushed before analysis. The inorganic geochemical composition ( $\mathrm{Si}, \mathrm{Al}, \mathrm{Fe}, \mathrm{Mn}, \mathrm{Ca}, \mathrm{Mg}, \mathrm{K}$, $\mathrm{Na}, \mathrm{Ti}, \mathrm{P}, \mathrm{S}$ ) of the fine sediment was determined on fusion beads by WD-XRF (Wave Dispersion X-Ray Fluorescence, S8 Tiger, Bruker®) analysis according to the procedure derived from Maghraoui et al. (1999). Calibration curves were established using a set of internal and international reference materials. The relative uncertainty obtained is lower than $1 \%$.

\section{3- Results}

\section{3-1) Geomorphologic study}

All computed parameters are compiled in Fig. 2 and Tab. 1. The Hercynian domain, in the upstream part of the studied catchments, shows a higher mean slope ( $25 \%$ ) than the Alpine one ( $20 \%$ ). Moreover, the morphology is clearly much steeper in the Hercynian domain (mean residual relief: $\sim 280 \mathrm{~m}$ ) than in the Alpine domain (mean residual relief: $175 \mathrm{~m}$ ). The limit between the Hercynian and the Alpine domains regarding slopes and the normalized steepness index values (Ksn) for each $1 \mathrm{~km}$-long stream portion is well marked (Fig. 2A). Upstream, the Golo and Tavignano are both glacial U-shaped valleys with steep 
flanks and flat bottoms (Fig. 2A). Ksn values vary from a factor of 1 to 10 in the Golo, Asco, and Tavignano rivers, indicating that some parts (with higher values) of the hydrographic network present anomalous slopes. These anomalies are located just downstream of the lowest glacial-shaped features suggesting a glacial imprint on the present-day morphology. A change in rock competence between the Alpine and Hercynian domains can also partly account for such Ksn differences. Only small anomalies can be seen in the Alpine domain. They may be explained by local lithologic contacts, for instance near the transition between ophilites and phyllites as seen by comparing Fig. 1B and Fig. 2A. The same kind of structurally induced dichotomy between the Alpine and Hercynian domains is visible on the residual relief map (Fig. 2B). Such a dichotomy is not easily noticeable on the main rivers' longitudinal profiles (Fig. 2C1; Fig. 2C2). Indeed, longitudinal profiles generally show classical concave-shaped profiles. Nevertheless, some knickpoints can be distinguished on many profiles, corresponding either to lithologic contacts (e.g. Bevinco; Fium Alto) or to transitions from glaciated to non-glaciated areas (e.g. Golo, Asco, Tavignano), in good agreement with Ksn values. These kind of observations have also been made in the Himalayas where knickzones have been mapped downstream of formerly glaciated basins (Korup and Montgomery, 2008), or in the Bolivian Andes where downstream increases of knickzones and concavities correspond to orographic reaches (Schlunegger et al., 2011). Some authors also suggest that these kinds of anomalies may be related to a local change in the uplift rate (Fellin et al., 2005b). The values of the hypsometric integrals range between 0.33 and 0.47 indicating an intermediate state between mature and non-mature drainage networks (Fig. 2C3; Tab. 1).

\section{3-2) Quantification of millennial-scale denudation rates}

The ${ }^{10} \mathrm{Be}$-derived denudation rates range from 15 to $95 \mathrm{~mm} . \mathrm{ka}^{-1}$ (Fig. 3), with most of them ranging between 40 and $60 \mathrm{~mm} \cdot \mathrm{ka}^{-1}$. Except for catchment 5 , integration times range between 7 to $18 \mathrm{ka}$ (Tab. 2). Catchments with the lowest values $\left(<40 \mathrm{~mm} \cdot \mathrm{ka}^{-1}\right)$ are mainly located north of the studied area and drain either the Hercynian (Asco (\# 5), the Tartagine (\# 3 )), or the Alpine (Lagani (\# 2), Bevinco (\# 1)) domains. The highest values (> $70 \mathrm{~mm} \cdot \mathrm{ka}^{-1}$ ) mainly concern catchments in the Alpine domain (Casaluna (\# 10), Fium Alto (\#12)), except for Restonica (\# 15), which is located in the Hercynian domain (Fig.3).

With the exception of two samples (5 and 14), the studied catchments present a maximum ice cover surface lower than $15 \%$ during less than $20 \%$ of the maximum integration time. This implies a measured ${ }^{10} \mathrm{Be}$ concentration of, at the most, $5 \%$ lower than would be measured for the same permanently non-glaciated catchment. Given the associated uncertainties, this does not significantly affect the apparent denudation rate. This 
is also the case for catchment 14 , with a maximum of $25 \%$ of the drainage surface having been covered by glaciers, but over $\sim 8 \%$ of the maximum integration period in the most adverse conditions. Sample 5 integrates a long time period ( $\sim 0 \mathrm{ka})$ that includes several climatic changes and glacier development on more than $50 \%$ of its surface (Tab. 2). In this case, the ${ }^{10} \mathrm{Be}$-derived denudation rate of $15.4 \pm 1.8 \mathrm{~mm} . \mathrm{ka}^{-1}$ represents an overestimation. Nevertheless, this denudation rate is already the lowest of the studied area, so an overestimation of this value do not change interpretations about processes responsible for such a low denudation. Considering this discussion about the significance of ${ }^{10} \mathrm{Be}$ concentrations in past glaciated areas, we decided to not exclude any data because of the presence of past glaciers in the following statistical analyses, even if the denudation rate determined from sample 5 has to be considered as overestimated.

The effective denudation rate was computed for catchments containing a nested part, i.e. 4, 7, 10, and 16. The rate is similar to that deduced from direct measurements for catchments 7 and 16 and is roughly $20-30 \%$ higher for catchments 4 and 10 . Taking into account the associated uncertainties, the sediment flux at the outlet of catchment 8 is consistent with the sum of the sediment fluxes of the Golo's upstream tributaries (\# 2, 3, 4, 7, and 10), indicating an efficient mixing of sediment up to this point which gives confidence to our results. This portion of the catchment (\# 8) is nonetheless too small to allow us to compute an accurate effective denudation rate. An effective denudation rate along the downstream part of the Golo (\# 9) cannot be computed because the sediment supply deduced from measured ${ }^{10} \mathrm{Be}$ concentrations do not show significant variations between the upstream (\# 8) and downstream (\# 9) parts of the catchment portion (Fig. 3; Tab. 2). This indicates that the sediments sampled from catchment 9 are mostly supplied by the upstream part of the catchment. The downstream portion of the Golo River provides a larger part of the finest material, so during sampling we probably miss the sediment resulting from denudation of this sector. Since it is not possible to compute an accurate effective denudation rate, we will exclude catchments 8 and 9 from our statistical analysis.

\section{3-3) Rock strength mapping}

Rebound values $(Q)$ range from $40 \pm 8$ for Miocene clayed sandstone to $73 \pm 5.5$ for rhyolite (Fig. 4A). Most of the rocks in the Alpine domain yield values lower than 60 , whereas the values are higher than 60 for most of the rocks in the Hercynian domain (Fig. 4B). The Alpine and Hercynian domains are made up of three main structural units: phyllites, Mesozoic sedimentary rocks (flysch, sandstone, and limestone), and ophiolitic complex in the Alpine domain, and a crystalline metamorphic basement, with granites and acid volcanic rocks in the Hercynian domain. Rebound values were averaged for each structural unit (Fig. 
4C). The measurements show that the three harder units belong to the Hercynian domain ( $65 \pm 9$; Fig. 4C) while the three softer are in the Alpine domain ( $53 \pm 12$; Fig. 4C). In order to compare the ${ }^{10} \mathrm{Be}$-derived denudation rates and mean catchment $\mathrm{Q}$ values, we have to assume that the quartz content is almost similar in each unit, even if it difficult to accurately estimate. Some specific rocks do not contain quartz (i.e. limestones) but they only represent a small part of the total drainage area. Quartz-bearing rocks are contained in all units (even ophiolites which are frequently cutted by acid crystalline dykes and quartz veins) and we estimate that the most extended rocks contain a similar $~ 30-50 \%$ quartz-content.

\section{3-4) Inferring vegetal cover and relation with exposition}

Nowadays, human activities are mainly concentrated in the alluvial plain. The repartition of vegetation is thus almost natural in most parts of the studied area. Vegetation in the Hercynian domain is often sparse or less developed, except for some coniferous forests located in high-elevation valleys. In many places, rocks are directly exposed. The Alpine domain is mainly covered by deciduous or mixed forests and sclerophyllous vegetation (Fig. $5 C$ ). Field expositions were calculated for each type of vegetation (Fig. 5A; 5B; 5C). Results show that the forests are mainly on NW-exposed slopes (Fig. 5B). This is especially true for coniferous and mixed forests, whereas transitional woodland-shrub domains do not develop on any preferential slope orientation. Areas covered by short vegetal species such as grassland or sclerophyllous are mainly on S- to SE-exposed slopes (Fig. 5A). Areas where rocks directly outcrop are also mainly orientated to the southeast (Fig. 5A). To summarize, vegetation was classified into two main groups: the short vegetation domain and the forest domain, respectively (Fig. 5A; 5B). More than $61 \%$ of the forests are on $\mathrm{N}$ - to $\mathrm{W}$-exposed slopes, whereas only $26 \%$ are on E- to S-exposed slopes. For the short vegetation, $50 \%$ is found on $\mathrm{E}$ - to S-exposed slopes, whereas only $27 \%$ is on $\mathrm{N}$ - to W-exposed slopes.

\section{3-5) $\mathrm{Al} / \mathrm{K}$ measurements reflecting the role of vegetation and/or lithology in weathering intensity}

The $\mathrm{Al} / \mathrm{K}$ ratio ranges from 1.6 to 4.4 (Table 3 and Fig. 6 ). It has been compared to bedrock strength and vegetation cover. Indeed, the combined presence of high vegetation (presence of forests) and soft bedrock promotes the efficiency of the weathering intensity and regolith formation. In both cases, despite the scattered data, a correlation is noticed with the $A l / K$ ratio $\left(R^{2}=0.64\right.$, linear for bedrock strength and $R^{2}=0.49$, linear for vegetal cover $)$ (Fig. 6C and Fig. 6D). The weaker the bedrock, the more important the forest cover in the catchment, and the higher the $\mathrm{Al} / \mathrm{K}$ ratio. Note that three samples $(46,48,79 ; \mathrm{Tab} .3)$ are excluded from the general regression lines. These samples result from the drainage of a large amount of ophiolites whose initial $\mathrm{K}_{2} \mathrm{O}$ concentration was significantly lower than that of 
other Corsican rocks (Grelou-Orsini, 1977; Bailly, 2004) (Fig. 6). The initial composition of the drained rocks indeed influences the $\mathrm{Al} / \mathrm{K}$ ratio (Bayon et al., 2012) when considering the $<45 \mu \mathrm{m}$ size fraction. This may also explain the scattering of the data (Fig. 6C and Fig. 6D). Nevertheless, the overall correlation between $\mathrm{Al} / \mathrm{K}$ ratio, rock strength and vegetal cover leads us to believe that the $\mathrm{Al} / \mathrm{K}$ ratio can adequately reflect the intensity of weathering in the studied area.

\section{3-6) Comparisons between denudation rates and morphometric indexes,} climate, lithology, and vegetal cover.

${ }^{10}$ Be-derived denudation rates are mostly integrated over a $\sim 15 \mathrm{ka}$ long time period. The climate in Corsica was colder in the past (Kuhlemann et al., 2008) and the vegetation was mainly constituted by steppes during late glacial and the first thousands years of the postglacial period (Reille et al., 1999). The present-day pattern of forests in Corsica has been nearly the same for the last 7-8 ka (Reille et al., 1999). This pattern is mainly controlled by constant parameters (exposition, altitude, relative humidity, type of substratum...). Without strong human activities, shifts in climate conditions would have only resulted in overall denser or sparser vegetation without significant changes in the spatial pattern of vegetation cover. In these conditions, the use of modern vegetation indices is reliable enough to assess relative distribution over similar integration periods (e.g. Portenga et al., 2015; Torres Acosta et al., 2015). Fig. 7 shows the relationship between the ${ }^{10} \mathrm{Be}$-derived denudation rates in the studied catchments and different morphometric and climatic parameters such as mean elevation (Fig. 7A), slope (Fig. 7B), local relief (Fig. 7C), normalized steepness indexes (Fig. 7D), and annual rainfall (Fig. 7G) (from the WorldClim database; Hijmans et al., 2005). We also compare ${ }^{10} \mathrm{Be}$-derived denudation rates with the mean rebound value $(\mathrm{Q})$, used as a proxy of catchment rock strength (Fig. 7E), and with modern vegetation cover (Fig. 7F) represented as the percentage of forests in the catchment.

At a first order, none of the morphometric parameters correlate with the deduced denudation rates $\left(R^{2}<0.05\right.$ for slope, Ksn, local relief, mean elevation), indicating that morphology is not the main factor controlling the denudation. Mean annual rainfall values do not correlate either $\left(R^{2}=0.17\right)$. Denudation rates present a better fit with rock strength (Fig. $7 E ; R^{2}=0.61$; linear) and percentage of forests $\left(R^{2}=0.42\right.$; linear); the softer the rock and the more developed the forest, the higher the denudation rate. Note that rock strength also partly correlates with vegetal cover, the forests being preferentially developed on softer rocks (Fig. $7 \mathrm{H})$. In detail, correlations between denudation, rock strength, and percentage of forest are mainly driven by the three same samples: 4,10 , and 12 . These samples correspond to the extreme values of both rock strength and denudation rates (Tab. 2). If we compute the same 
relationships without these three samples, correlations with rock strength and vegetation weaken ( $R^{2}=0.05$ for both parameters), whereas correlations with morphometric indexes significantly increase $\left(R^{2}=0.33\right.$ for mean elevation; $R^{2}=0.54$ for mean slope; $R^{2}=0.37$ for local relief; $R^{2}=0.43$ for Ksn; Fig. 7 ). It appears that rock strength and/or vegetation controls denudation rates at a first order but when values of these two parameters are weakly distributed, a correlation between denudation rates and morphology can be noticed.

\section{4- Discussion}

\section{4-1) Comparison with previously determined denudation rates}

Denudation rates deduced for Corsica catchments are quite low in comparison with rates determined in the foreland of the northern European Alps, which present a similar geomorphic context (Wittmann et al., 2007; Norton et al., 2011; Molliex et al., 2016).

The contemporary averaged sediment flux (bedload and suspended load) estimated from measurements performed at the Golo River outlet during the August $27^{\text {th }} 1975$ flood

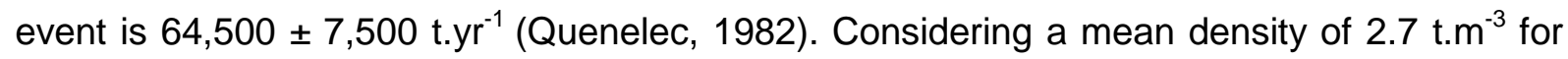
the eroded rocks, the corresponding deduced denudation rate is $23 \pm 2.7 \mathrm{~mm} . \mathrm{ka}^{-1}$. This value is about half that deduced from ${ }^{10} \mathrm{Be}$ concentration measurements, that is $46.5 \pm 9.4 \mathrm{~mm} . \mathrm{ka}^{-1}$ integrated over the last $13.5 \mathrm{ka}$ (catch. 9, Fig. 3, Tab. 2). Due to the rather short time period integrated when performing the direct sediment flux measurement method, extreme flood events such as millennial or centennial floods are not necessary recorded, which may lead to significant underestimations of fluxes in torrential or particular hydrological domains (watersheds highly sensitive to sudden floods, for instance) (Kirchner et al., 2001; Serrat et al., 2001; Molliex et al., 2016).

Conversely, a Holocene denudation rate of $48 \pm 25.3 \mathrm{~mm} \cdot \mathrm{ka}^{-1}$ was deduced from the estimation of sediment volumes deposited offshore (Calvès et al., 2013; unit 3; last 16 ka; 61.5 to $198 \mathrm{t} . \mathrm{km}^{2} . \mathrm{yr}^{-1}$ ), similar to that deduced from in situ-produced ${ }^{10} \mathrm{Be}$ concentration measurements. Nonetheless, denudation rates deduced onshore could be inconsistent with sediment flux deduced offshore because of the increase of sediment storage in the catchment during glacial periods (Harbor and Warburton, 1993; Hinderer, 2012). Indeed, glacial denudation leads to the formation of moraines, which are preserved during the glacial period because of the lower precipitation rate and the lower transport capacity due to water discharge. Moraines could thus constitute a significant volume of stored sediment that can easily be mobilized during deglacial and interglacial periods when fluvial processes become more efficient, yielding then to a higher sediment flux during interglacial periods. In the case of eastern Corsica the relatively small extension of several preserved moraines (Krumrei, 
2009; Kuhlemann et al., 2009) should not influence denudation rates inferred from sediment fluxes.

\section{4-2) A peri-glacial environment at steady-state equilibrium during Holocene ?}

Long-term (Quaternary) denudation rates inferred from in situ-produced ${ }^{10} \mathrm{Be}$ concentration measurements on granitic crests ranged from 8 to $20 \mathrm{~mm} \cdot \mathrm{ka}^{-1}$ in the Golo catchment (Kuhlemman et al., 2007; 2009). The late Quaternary incision rate of bedrock by the main Golo stream, inferred from OSL-dated terraces geometry, ranges from 160 to $475 \mathrm{~mm} . \mathrm{ka}^{-1}$ (Fellin et al., 2005a; Sømme et al., 2011). The ${ }^{10}$ Be derived catchment-scale denudation rate determined for the Golo catchment in this study thus ranges between those estimated for the crests and the main stream. In catchments where stream incision is more efficient than denudation of the crests, the main stream location corresponds to the most effective denudation zone and the crests are significantly less eroded, inducing an increase in relief (e.g. Whipple et al., 1999; Meyer et al., 2010; Yanites and Ehlers, 2012; Champagnac et al., 2014). This relief-increase model for the Golo is supported by the stair-cased geometry of terraces in the catchment, indicating the efficient incision of the stream at the Quaternary scale.

In glacial and peri-glacial environments such as Corsica, three main climatic phases can be distinguished through changes in sediment fluxes and sedimentary patterns (e.g. Church and Ryder, 1972; Hinderer, 2012). The glacial phase leads to an onshore incision, a strong frostcracking, and eolian alteration. The deglacial phase leads to a strong phase of aggradation due to sea level rise and a high sediment supply controlled by glacial melting and moraine degradation. This phase leads to the deposit of braided terraces. After the sediment supply peak due to the deglaciation, sediment fluxes decrease exponentially and approach an interglacial equilibrium (Ballantyne, 2002).

In a fluvial environment, channel steepening is linked to uplift and denudation rates. Channel steepness is thus a reliable proxy that allows us to investigate these parameters (e.g. Anhert, 1970; Schmidt and Montgomery, 1995; Roering et al., 1999, 2001; Montgomery and Brandon, 2002; DiBiase et al., 2012). The presented quantitative geomorphology study in Corsica shows that glacial processes in the upstream part of the main catchments have impacted the hydrographic network. On the other hand, global studies indicate that morphology often controls denudation rates in such steep environments (e.g. Montgomery and Brandon, 2002; Portenga and Bierman, 2011; Willenbring et al., 2013). In the northern European Alps, ${ }^{10} \mathrm{Be}$-derived denudation rates appear to be partly correlated with geomorphic metrics such as slope or relief (Wittmann et al., 2007; Delunel et al., 2010; Norton et al., 2011; Glotzbach et al., 2013; Molliex et al., 2016). 
${ }^{10} \mathrm{Be}$ deduced denudation rates for Corsica can be considered as representative for the Holocene, an interglacial period characterized by a warm and relatively wet climate (Reille et al., 1997; 1999). The fact that denudation rates which integrate nearly all the Holocene period still almost stable despite strong differences in morphologic indexes suggest that Corsica reached the interglacial equilibrium described by Ballantyne (2002).

\section{Corsica.}

553

554

555

556

557

558

559

560

561

562

563

564

565

566

567

568

569

570

571

572

573

574

575

576

577

578

579

580

581

When the differences in rock strength and/or vegetation cover are significant, denudation rates in Corsica, even if they still low, seem more evidently linked to rock strength and vegetation than to morphology. Because forests are more developed in the Alpine domain, where rocks are softer, than in the Hercynian domain, it is difficult to decipher whether vegetation or rock strength mainly controls the denudation rates. We showed that land exposure plays an important role in vegetal cover distribution, forests being welldeveloped on $\mathrm{N}$ - to $\mathrm{W}$-exposed land, whereas $\mathrm{S}$ - to $\mathrm{E}$-exposed land is preferentially covered by short vegetation. This repartition could be explained by climatic parameters. Indeed, the "Libecciu", the prevailing wet wind in Corsica, blows from the west (Benevent, 1914; Brandmeier et al., 2011). Brandmeier et al. (2011) previously pointed out the importance of westward winds such as the "Libecciu" in the particular weathering of Corsican granites characterized by the development of westward-oriented tafoni (erosional features in granites). North-exposed lands have less sun exposure at a daily scale and are thus more prone to keep humidity, which favors vegetation growing. The vegetation development increases the efficiency of pedogenic processes: the more the vegetation is developed, the more the soil and regolith are developed. Correlations between the $\mathrm{Al} / \mathrm{K}$ ratio, percentage of forests, and bedrock strength could suggest that the chemical weathering of the bedrock and thus the development of the regolith is controlled by the vegetation and type of rocks. Norton et al. (2014) demonstrated that at a low denudation rate, regolith production is poorly related to changes in precipitation rate and temperature. This may explain why precipitation rates, even if the resolution of the climatic data is poor in the studied area (WorldClim database; Hijmans et al., 2005), do not correlate with ${ }^{10} \mathrm{Be}$-derived denudation rates (Fig. 7G). The denudation rates in Corsica might thus to be directly related to the regolith development, the chemical weathering being more efficient than the physical processes in the denudation process. Some studies also demonstrate a better correlation of denudation rates with lithology and regolith development than with morphometric parameters, even in mountainous environments (Clapp et al., 2001; Morel et al., 2003; Palumbo et al., 2009). Indeed, in those cases, rock strength is directly presented as being responsible for a more efficient regolith production due to rock structures (joints, dipping, schistosity) (Densmore et al., 2007). 
The size of the studied catchments may be an important parameter since correlation between morphologies and denudation rates is often highlighted for large catchments or small catchments in tectonically active settings (e.g. Riebe et al., 2000) while studies concluding to a non-correlation between morphometric indexes and denudation rates often concern small catchments in non-tectonically active settings $\left(<500 \mathrm{~km}^{2}\right.$; Palumbo et al., 2009; Roller et al., 2012). Indeed, it has been suggested that in large catchments, spatial variations of denudation rates linked to local parameters such as lithology or vegetation are averaged (Summerfield and Hulton, 1994; Palumbo et al., 2009).

\section{Conclusion}

Millenial-scale ${ }^{10}$ Be-derived denudation rates obtained from the Golo sub-basins and surrounding catchments are quite low, almost spatially stable and do not correlate at first order with geomorphic metrics (such as slope, relief, steepness, mean elevation...), as it is usually the case in similar geodynamic and geomorphologic settings. This suggests that Corsica's landscape reached an interglacial steady-state equilibrium that might be caused by the specific characteristics of the Mediterranean climate. Based on catchment mean rock strength (Schmidt Hammer measurements) and vegetation cover distribution, we highlighted that the rock strength and spatial distribution of the vegetation probably play a significant role in the denudation distribution. The pattern of vegetation is partly controlled by its exposure to the sun and the direction of the main regional wet-wind (so-called "Libecciu"). Even if it is difficult to decipher the role of each parameter, we suggest that regolith formation by chemical weathering is the main parameter controlling denudation in mountainous environment experiencing such climatic context. Indeed, higher denudation rates are located in areas where conditions are the most favorable for the development of regolith (weak bedrock or/and developed vegetation). Al/K ratio measurements also support a weathering efficiency linked to the development of the vegetation and/or to the strength of the substratum. The small size of the studied catchments might play a role in the fact that shortterm denudation rates better reflect local processes such as regolith formation rather than the catchment's general morphology.

\section{Aknowledgements}

S. Molliex benefited from a post-doc fellowship granted by LabexMER and IFREMER. This work further benefited from a State Grant from the French "Agence Nationale de la Recherche (ANR)" in the Program "Investissements d'Avenir" (ANR-10-LABX-19-01, Labex Mer). The French CNRS INSU SYSTER partly financed the cosmogenic nuclide concentration measurements. We thank L. Léanni, M. Arnold, G. Aumaître, and K. Keddadouche for their valuable assistance during ${ }^{10} \mathrm{Be}$ measurements at the ASTER AMS 
national facility (CEREGE, Aix en Provence), which is supported by the INSU/CNRS, the ANR through the "Projets thématiques d'excellence" program for the "Equipements d'excellence" ASTER-CEREGE action, IRD and CEA. We thank B. Drussel and E. Gautier for their assistance in the field. We are also grateful to P. Bierman, F. Schlunegger and 2 anonymous reviewers for their fruitful comments which contributed to improve the manuscript. K. Kovacs post-edited the English style.

\section{References}

624

625

626

627

628

629

630

631

632

633

634

635

636

637

638

639

640

641

642

643

644

645

646

647

648

649

650

651

652

653

654

655

Ahnert F. 1970. Functional relationship between denudation, relief, and uplift in large mid-latitude drainage basins. American Journal of Science 268: 243-263.

Ahnert F. 1984. Local relief and the height limits of mountain ranges. American Journal of Science 284: 1035-1055.

Allen PA. 1997. Earth Surface Processes. Blackwell: London; 404 pp..

Arnold M, Merchel S, Bourles DL, Braucher R, Benedetti L, Finkel RC, Aumaître G, Gottdang A, Klein M. 2010. The French accelerator mass spectrometry facility ASTER: Improved performance and developments. Nuclear Instruments and Methods in Physics Research B 268: 1954-1959.

Aydin A, Basu A. 2005. The Schmidt hammer in rock material characterization. Engineering Geology 81: $1-14$.

Bailly L. 2004. Séquestration ex-situ du $\mathrm{CO}_{2}$. Inventaire français des roches basiques et ultrabasiques. BRGM report: BRGM/RP-53511-FR; 28 pp.

Balco G. 2001. Cosmogenic Isotope Production Rates Over Large Areas. http://depts.washington.edu/cosmolab/P_by_GIS.html

Ballantyne CK. 2002. A general model of paraglacial landscape response. The Holocene 12(3): 371376.

Baran R, Friedrich AM, Schlunegger F. 2014. The late Miocene to Holocene erosion patter of the Alpine foreland basin reflects Eurasian slab unloading beneath the western Alps rather than global climate change. Lithosphere 6 (2): 124-131.

Basu A, Aydin A. 2004. A method for normalization of Schmidt hammer rebound values. Int. J. Rock Mech. Min. Sci. 41: 1211-1214.

Bayon G, Dennielou B, Etoubleau J, Ponzevera E, Toucanne S, Bermell S. 2012. Intensifying weathering and land use in Iron Age Central Africa. Science 335: 1219-1222.

Bénévent E. 1914. La pluviosité de la Corse. Recueil des travaux de l'institut de géographie alpine 2 (2): 239-264.

Bermudez MA, van der Beek PA, Bernet M. 2013. Strong tectonic and weak climatic control on exhumation rates in the Venezuelan Andes. Lithosphere 5: 3-16.

Bierman P, Steig EG. 1996. Estimating denudation using cosmogenic isotope abundances in sediment. Earth Surf. Process. Landforms 21: 125-139.

Bonnet S, Crave A. 2003. Landscape response to climate change: Insights from experimental modeling and implications for tectonic versus climatic uplift of topography. Geology 31: 123126. 
Bookhagen B, Strecker MR. 2012. Spatiotemporal trends in erosion rates across a pronounced rainfall gradient: Examples from the southern Central Andes. Earth Planet. Sc. Lett. 327-328: 97-110.

Brandmeier M, Kuhlemann J, Krumrei I, Kappler A, Kubik PW. 2011. New challenges for tafoni research. A new approach to understand processes and weathering rates. Earth Surf. Process. Landforms 36: 839-852.

Brandon MT, Roden-Tice MK, Garver JI. 1998. Late Cenozoic exhumation of the Cascadia accretionary wedge in the Olympic Mountains, northwest Washington State. Geol. Soc. Am. Bull. 110: 985-1009.

Braucher R, Merchel S, Borgomano J, Bourlès DL. 2011. Production of cosmogenic radionuclides at great depth: a multi element approach. Earth Planet. Sci. Lett. 309: 1-9.

Brocklehurst SH, Whipple KX. 2002. Glacial erosion and relief production in the Eastern Sierra Nevada, California. Geomorphology 42: 1-24.

Brown ET, Edmond JM, Raisbeck GM, Yiou F, Kurz MD, Brook EJ. 1991. Examination of surface exposure ages of Antarctic moraines using in situ produced ${ }^{10} \mathrm{Be}$ and ${ }^{26} \mathrm{Al}$, Geochimica and Cosmochimica Acta 55: 2269-2283.

Brown ET, Stallard RF, Larsen MC, Raisbeck GM, Yiou F. 1995. Denudation rates determined from the accumulation of in situ-produced ${ }^{10} \mathrm{Be}$ in the Luquillo Experimental Forest, Puerto Rico, Earth Planet. Sci. Lett. 129: 193-202.

Brunet C, Monié P, Jolivet L, Cadet J-P. 2000. Migration of compression and extension in the Tyrrhenian Sea, insights from ${ }^{40} \mathrm{Ar} /{ }^{39} \mathrm{Ar}$ ages on micas along a transect from Corsica to Tuscany. Tectonophysics 321: 127-155.

Cacho I, Grimalt JO, Canals M. 2002. Response of the western Mediterranean Sea to rapid climatic variability during the last 50,000 years: a molecular biomarker approach. Journal of Marine Systems 33-34: 253-272.

Calvès G, Toucanne S, Jouet G, Charrier S, Thereau E, Etoubleau J, Marsset T, Droz L, Bez M, Jorry S, Mulder T, Lericolais G. 2013. Inferring denudation variations from the sediment record; An example of the last glacial cycle record of the Golo basin and watershed, East Corsica, Western Mediterranean Sea. Basin Research 24: 1-22.

Cavazza W, Zattin M, Ventura B, Zuffa GG. 2001. Apatite fission-track analysis of Neogene exhumation in northern Corsica (France). Terra Nova 13: 51-57.

Champagnac J-D, Molnar P, Sue C, Herman F. 2012. Tectonics, Climate, and Mountain Topography. J. Geophys. Res. B: Solid Earth 117: B02403.

Champagnac J-D, Valla PG, Herman F. 2014. Late-Cenozoic relief evolution under evolving climate: A review. Tectonophysics 614: 44-65.

Chantraine J, Autran A, Cavelier C. 1996. Geological map of France (1/1 000 000). Ed. BRGM: Orléans.

Chittenden H, Delunel R, Schlunegger F, Akçar N, Kubik PW. 2014. The influence of bedrock orientation on the landscape evolution, surface morphology and denudation (10Be) at the Niesen, Switzerland. Earth Surface Processes and Landforms 39 (9): 1153-1166. 
Chmeleff $\mathrm{J}$, von Blanckenburg F, Kossert K, Jakob J. 2010. Determination of the ${ }^{10} \mathrm{Be}$ half-life by multicollector ICP-MS and liquid scintillation counting. Nuclear Instruments and Methods in Physics Research B 268: 192-199.

Church M, Ryder JM. 1972. Paraglacial sedimentation: A consideration of fluvial processes conditioned by glaciations. Geol. Soc. Am. Bull. 83: 3059-3072.

Clapp EM, Bierman PR, Nichols KK, Pavich M, Caffee M. 2001. Rates of sediment supply to arroyos from upland erosion determined using in situ produced cosmogenic ${ }^{10} \mathrm{Be}$ and ${ }^{26} \mathrm{Al}$, Quaternary Research 55: 235-245.

Collina-Girard J. 1999. Les replats littoraux holocènes immerges en Provence et en Corse: implications eustatiques et néotectoniques. Quaternaire 10(2-3): 121-131.

Conchon O. 1978. Quaternary studies in Corsica (France). Quaternary Research 9(1): 41-53.

Conchon O. 1999. Le littoral de Corse (France) au Quaternaire. Quaternaire 10: 95-105.

Cruz Nunes F, Delunel R, Schlunegger F, Akçar N, Kubik PW. 2015. Bedrock bedding, landsliding and erosional budgets in the Central European Alps. Terra Nova 27 (5): 370-378.

Cubells JF, Ferrandini J, Ferrandini M, Gaudant J, Loÿe-Pilot MD. 1994. Présence du genre Aphanius NARDO, famille des Cyprinodontidae, dans le Miocène du Bassin de Francardo Ponte Leccia (Corse). Geol. Mediterr. 21:19-24.

Daniel JM, Jolivet L, Goffe B, Poinssot C. 1996. Crustal-scale strain partitioning: Footwall deformation below the Alpine Oligo-Miocene detachment of Corsica. J. Struct. Geol. 18: 41-59.

Daniśík M, Kuhlemann J, Dunkl I, Székely B, Frisch W. 2007. Burial and exhumation of Corsica (France) in the light of fission track data. Tectonics 26: TC1001.

Daníšík M, Kuhlemann J, Dunkl I, Evans NJ, Székely B, Frisch W. 2012. Survival of ancient landforms in a collisional setting as revealed by combined fission track and (U-Th)/He thermochronometry: A case study from Corsica (France). Jounal of Geology 120(2): 155-173.

Davies TA, Hay WW, Southam JR, Worsley TR. 1977. Estimates of cenozoic oceanic sedimentation rates. Science 197: 53-55.

Delunel R, van der Beek PA, Carcaillet J, Bourlès DL, Valla PG. 2010. Frost-cracking control on catchment denudation rates: Insights from in situ produced ${ }^{10} \mathrm{Be}$ concentrations in stream sediments (Ecrins-Pelvoux massif, French Western Alps). Earth Planet. Sci. Lett. 293:72-83.

Densmore AL, Gupta S, Allen PA, Dawers NH. 2007. Transient landscapes at fault tips. J. Geophys. Res. 112: F03S08. doi:10.1029/2006JF000560.

DiBiase RA, Whipple KX, Heimsath AM, Ouimet WB. 2010. Landscape form and millennial erosion rates in the San Gabriel Mountains, CA. Earth Planet. Sci. Lett. 289: 134-144.

DiBiase RA, Heimsath AM, Whipple KX. 2012. Hillslope response to tectonic forcing in threshold landscapes. Earth Surf. Process. Landforms 37: 855-865.

Duvall A, Kirby E, Burbank D. 2004. Tectonic and lithologic controls on bedrock channel profiles and processes in coastal California. J. Geophys. Res. 109: F03002, doi:10.1029/2003JF000086.

Dunai T. 2010. Cosmogenic nuclides: principles, concepts and applications in the earth surface sciences. Cambridge University Press; 187 pp. 
Engel Z, Braucher R, Traczyk A, Leanni L, AsterTeam. 2014. ${ }^{10} \mathrm{Be}$ exposure age chronology of the last glaciation in the Krkonose Mountains, Central Europe. Geomorphology 206: 107-121.

Fellin MG, Zattin M, Picotti V, Reiners PW, Nicolescu S. 2005a. Relief evolution in northern Corsica (western Mediterranean): Constraints on uplift and erosion on long-term and short-term timescales. J. Geophys. Res. 110: F01016, doi: 10.1029/2004JF000167.

Fellin MG, Picotti V, Zattin M. 2005b. Neogene to Quaternary rifting and inversion in Corsica: retreat and collision in the western Mediterranean. Tectonics 24: TC1011, doi:10.1029/2003TC001613.

Fellin MG, Vance JA, Garver JI, Zattin M. 2006. The thermal evolution of Corsica as recorded by zircon fission-tracks. Tectonophysics 421: 299-317.

Ferrandini M, Ferrandini J, Loÿe-Pilot M D, Butterlin J, Cravatte J, Janin MC. 1998. Le Miocène du bassin de Saint-Florent (Corse); modalités de la transgression du Burdigalien supérieur et mise en evidence du Serravallien. Geobios 31:125-137.

Flint JJ. 1974. Stream gradient as a function of order, magnitude, and discharge. Water Resour. Res. 10(5): 969-973.

Fournier M, Jolivet L, Goffé B, Dubois R. 1991. Alpine Corsica metamorphic core complex. Tectonics 10: 1173-1186.

Gattacceca J, Deino A, Rizzo R, Jones DS, Henry B, Beaudoin B, Vadeboin F. 2007. Miocene rotation of Sardinia: New paleomagnetic and geochronological constraints and geodynamic implications. Earth Planet. Sc. Lett. 258: 359-377.

Gibbons W, Horak J. 1984. Alpine metamorphism of Hercynian hornblende granodiorite beneath the blueschists facies Schistes Lustrés nappe of NE Corsica. J. Metamorph. Geol. 2: 95-113.

Glotzbach C, van der Beek PA, Carcaillet J, Delunel R. 2013. Deciphering the driving forces of erosion rates on millenial to million-year timescales in glacially impacted landscapes: An example from the Western Alps. J. Geophys. Res. Earth Surf. 118: 1491-1515, doi: 10.1002/jgrf.20107.

Godard V, Bourlès DL, Spinabella F, Burbank D, Bookhagen B, Fisher GB, Moulin A, Leanni L. 2014. Dominance of tectonics over climate in Himalayan denudation. Geology 42: 243-246.

Gosse JC, Phillips FM. 2001. Terrestrial in situ cosmogenic nuclides: theory and application. Quaternary Science Reviews 20: 1475-1560.

Goudie AS. 2006. The Schmidt Hammer in geomorphological research. Progress in Physical Geography 30(6): 703-718.

Granger DE, Kirchner JW, Finkel RC. 1996. Spatially-averaged long-term erosion rates measured from in situ-produced cosmogenic nuclides in alluvial sediment. Journal of Geology 104: 249257.

Grelou-Orsini C. 1977. Données nouvelles sur les granites de Corse: géologie et érosion différentielle. Méditerranée 1: 35-44.

Hack JT. 1957. Studies of longitudinal profiles in Virginia and Maryland. US Geological survey Professional Paper 294.

Harbor J, Warburton J. 1993. Relative rates of glacial and nonglacial erosion in alpine environments. Arctic and Alpine Research 25(1): 1-7. 
Harris LB. 1985. Direction changes in thrusting of the Schists Lustres in Alpine Corsica. Tectonophysics 120: 37-56.

Henck AC, Huntington KW, Stone JO, Montgomery DR, Hallet B. 2011. Spatial controls on erosion in the Three Rivers Region, southeastern Tibet and southwestern China. Earth Planet. Sci. Lett. 303: 71-83.

Hijmans RJ, Cameron SE, Parra JL, Jones PG, Jarvis A. 2005. Very high resolution interpolated climate surfaces for global land areas. International Journal of Climatology 25: 1965-1978.

Hinderer M. 2001. Late Quaternary denudation of the Alps, valley and lake fillings and modern river loads. Geodinamica Acta 14: 231-263.

Hinderer M. 2012. From gullies to mountain belts: A review of sediment budgets at various scales. Sedimentary Geology 280: 21-59.

Howard AD, Kerby G. 1983. Channel changes in badlands. Geol. Soc. Am. Bull. 94: 739-752.

Howard AD, Dietrich WE, Seidl MA. 1994. Modeling fluvial erosion on regional to continental scales. J. Geophys. Res. 99: 13971-13986.

Hurtrez J-E, Lucazeau F. 1999. Lithological control on relief and hypsometry in the Hérault drainage basin (France). C. R. Acad. Sc. Earth and Planetary Sciences 328: 687-694.

Hurtrez J-E, Sol C, Lucazeau F. 1999. Effect of drainage area on hypsometry from an analysis of small-scale drainage basins in the Siwalik Hills (central Nepal). Earth Surf. Process. Landforms 24: 799-808.

Jolivet L, Daniel JM, Fournier M. 1991. Geometry and kinematics of ductile extension in Alpine Corsica. Earth Planet. Sci. Lett. 104: 278-291.

Jolivet L, Faccena C, Goffé B, Mattei M, Rossetti F, Brunet C, Storti F, Funiciello R, Cadet J-P, d'Agostino N, Parra T. 1998. Midcrustal shear zones in postorogenic extension: Example from the northern Tyrrhenian Sea. J. Geophys. Res. 103(B6): 12123-12160, doi:10.1029/97JB03616.

Jorry SJ, Jegou I, Emmanuel L, Silva Jacinto R, Savoye B. 2011. Turbiditic levee deposition in response to climate changes: the Var Sedimentary Ridge (Ligurian Sea). Marine Geology 279: 148-161.

Kirby E, Whipple KX. 2012. Expression of active tectonics in erosional landscapes. J. Struct. Geol. 44: 54-75.

Kirchner JW, Finkel RC, Riebe CS, Granger DE, Clayton JL, King JG, Megahan WF. 2001. Mountain erosion over 10 yr, 10 k.y., and 10 m.y. time scales. Geology 29(7): 591-594.

Klaer W. 1956. Verwitterungsformen im Granit auf Korsika. Petermanns geographische Mitteilungen, Ergän-zungsheft 261: 146 pp.

Kohl CP, Nishiizumi K. 1992. Chemical isolation of quartz for measurement of in-situ produced cosmogenic nuclides. Geochimica et Cosmochimica Acta 56: 3583-3587.

Korschinek G, Bergmaier A, Faestermann T, Gerstmann UC, Knie K, Rugel G, Wallner A, Dillmann I, Dollinger G, Lierse von Gostomski C, Kossert K, Maitia M, Poutivtsev M, Remmert A. 2010. A new value for the half-life of ${ }^{10} \mathrm{Be}$ by Heavy-Ion Elastic Recoil Detection and liquid scintillation counting. Nuclear Instruments and Methods in Physics Research B. 268: 187-191. 
Korup O, Montgomery DR. 2008. Tibetan plateau river incision inhibited by glacial stabilization of the Tsangpo gorge. Nature 455: 786-789.

Krumrei I. 2009. Wuermian glaciation and climate in the western Mediterranean based on investigations in the mountain chain of Corsica. PhD thesis: Tübingen University; 143 pp.

Kuhlemann J, Székely B, Frisch W, Daníšík M, Dunkl I, Molnar G, Timar G. 2005a. DEM analysis of mountaineous relief in a crystalline basement block:Cenozoic relief generations in Corsica (France). Z. Geomorph. N. F. 49(1): 1-21.

Kuhlemann J, Frisch W, Székely B, Dunkl I, Daníšík M, Krumrei I. 2005b. Würmian maximum glaciation in Corsica: glacier extent, amplifying paleorelief, and mesoscale climate. Austrian J. Earth Sci. 97: 68-81.

Kuhlemann J, Van der Borg K, Daniš́ík M, Frisch W. 2007. In situ ${ }^{10}$ Be-rosion rates in granites of subalpine Miocene paleosurfaces in the western Mediterranean (Corsica, France). Int. J. Earth Sci. 97: 549-564.

Kuhlemann, J, Rohling EJ, Krumrei I, Kubik P, Ivy-Ochs S, Kucera M. 2008. Regional synthesis of Mediterranean atmospheric circulation during the Last Glacial Maximum. Science 321: 13381340.

Kuhlemann J, Krumrei I, Daníšík M, Van der Borg K. 2009. Weathering of granite and granitic regolith in Corsica: short-term ${ }^{10} \mathrm{Be}$ versus long-term thermochronological constraints, In: Thermochronological Methods: From Palaeotemperature Constraints to Landscape Evolution Models (Ed. by F. Lisker, B.Ventura \& U.A. Glasmacher). Geol. Soc. London Spec. Publ. 324: 217-235.

Lal D. 1991. Cosmic ray labeling of erosion surfaces: in situ nuclide production rates and erosion models. Earth Planet. Sci. Lett. 104: 424-439.

Lenôtre N, Ferrandini J, Delfau M, Panighi J. 1996. Mouvements verticaux actuels de la Corse (France) par comparaison de nivellements. C. R. Acad. Sc. Serie II, Sciences de la Terre et des Planètes 323: 957-964.

Litty C, Duller R, Schlunegger F 2016. Paleohydraulic reconstruction of a 40 ka-old terrace sequence implies that water discharge was larger than today. Earth Surface Processes and Landforms: DOI: $10.1002 /$ esp.3872

Loÿe-Pilot M-D, Durand-Delga M, Feinberg H, Gourinard Y, Magne J. 2004. Les formations burdigaliennes de Corse orientale dans leur cadre géodynamique. C. R. Geosciences 336: 919-930.

Lucazeau F, Hurtrez J-E. 1997. Length-scale dependence of relief along the southeastern border of Massif Central (France). Geophys. Res. Lett. 24(14): 1823-1826.

Maghraoui ME, Joron J-L, Etoubleau J, Cambon P, Treuil M. 1999. Determination of Forty Four Major and Trace Elements in GPMA Magmatic Rock Reference Materials using X-ray Fluorescence Spectrometry (XRF) and Instrumental Neutron Activation Analysis (INAA). Geostandards Newsletter 23: 59-68. 
Matmon A, Bierman P, Larsen J, Southworth S, Pavich M, Finkel RC, Caffee M. 2003. Erosion of an ancient mountain range, the Great Smoky Mountains, North Carolina and Tennessee. Am. J. Sci. 303: 817-855.

Mattauer M, Faure M, Malavieille J. 1981. Transverse lineation and large scale structures related to Alpine obduction in Corsica. J. Struct. Geol. 3: 401-409.

Mauffret A, Gorini C. 1996. Structural style and geodynamic evolution of Camargue and Western Provençal basin, southeastern France. Tectonics 15: 356-375.

Merchel S, Herpers U. 1999. An update on radiochemical separation techniques for the determination of long-lived radionuclides via accelerator mass spectrometry. Radiochimica Acta 84: 215-219.

Merchel S, Arnold M, Aumaitre G, Benedetti L, Bourlès DL, Braucher R, Alfimov V, Freeman SPHT, Steier P, Wallner A. 2008. Towards more precise ${ }^{10} \mathrm{Be}$ and ${ }^{36} \mathrm{Cl}$ data from measurements at the $10^{-14}$ level: Influence of sample preparation. Nuclear Instruments and Methods in Physics Research B 266: 4921- 4926.

Meyer H, Hetzel R, Fügenschuh B, Strauss H. 2010. Determining the growth rate of topographic relief using in-situ-produced ${ }^{10} \mathrm{Be}$ : a case study in the Black Forest, Germany. Earth Plan. Sci. Lett. 290: 391-402.

Mix AC, Bard E, Schneider R. 2001. Environmental processes of the ice age: land, oceans, glaciers (EPILOG). Quaternary Science Reviews 20: 627-657.

Molliex S, Siame L, Bourlès DL, Braucher R, Bellier O, Clauzon G. 2013. Quaternary evolution of a large alluvial fan in a peri-glacial setting (Crau plain, SE France), constrained by terrestrial cosmogenic nuclide $\left({ }^{10} \mathrm{Be}\right)$. Geomorphology 195: 45-52.

Molliex S, Rabineau M, Leroux E, Bourlès DL, Authemayou C, Aslanian D, , Chauvet F, Civet F, Jouët G. 2016. Multi-approach quantification of denudation rates in the Gulf of Lion source-to-sink system (SE France). Earth and Planetary Science Letters 444: 101-115.

Molnar P, England P. 1990. Late Cenozoic uplift of mountain ranges and global climate change: chicken or egg? Nature 346: 29-34.

Molnar P, Anderson RS, Anderson SP. 2007. Tectonics, fracturing of rock, and erosion. J. Geophys. Res. 112: F03014, doi:10.1029/2005JF000433.

Montgomery DR, Brandon MT. 2002. Topographic controls on erosion rates in tectonically active mountain ranges. Earth Planet. Sci. Lett. 201: 481-489.

Morel P, von Blanckenburg F, Schaller M, Kubik PW, Hinderer M. 2003. Lithology, landscape dissection and glaciation controls on catchment erosion as determined by cosmogenic nuclides in river sediment (the Wutach Gorge, Black Forest). Terra Nova 15: 398-404.

Norton KP, Abbuhl LM, Schlunegger F. 2010. Glacial conditioning as an erosional driving force in the central Alps. Geology 38: 655-658.

Norton KP, von Blanckenburg F, DiBiase R, Schlunegger F, Kubik PW. 2011. Cosmogenic ${ }^{10} \mathrm{Be}-$ derived denudation rates of the Eastern and Southern European Alps. Int. J. Earth Sci. 100(5): 1163-1179.

Norton KP, Molnar P, Schlunegger F. 2014. The role of climate-driven chemical weathering on soil production. Geomorphology 204: 510-517. 
Ouimet WB, Whipple KX, Granger DE. 2009. Beyond threshold hillslopes: Channel adjustment to base-level fall in tectonically active mountain ranges. Geology 37: 579-582.

Orszag-Sperber F, Pilot M-D. 1976. Grands traits du Néogène de Corse. Bull. Soc. Geol. Fr. 18(5): 1183-1187.

Palumbo L, Hetzel R, Tao M, Li X. 2009. Topographic and lithologic control on catchment-wide denudation rates derived from cosmogenic ${ }^{10} \mathrm{Be}$ in two mountain ranges at the margin of NE Tibet. Geomorphology 117: 130-142.

Portenga EW, Bierman PR. 2011. Understanding Earth's eroding surface with ${ }^{10} \mathrm{Be}$. GSA Today 21: 4-10.

Portenga EW, Bierman PR, Duncan C, Corbett LB, Kehrwald NM, Rood DH. 2015. Erosion rates of the Buthanese Himalaya determined using in situ-produced 10Be. Geomorphology 233: 112126.

Quelennec RE, Dominici R, Juncy G, Rouire J. 1982. Le delta du Golo (Haute Corse). Dynamique sédimentaire du littoral et des bassins versants associés (Bevinco, Golo, Fium Alto). Géochimie des sédiments marins. Détermination des zones sensibles à l'érosion. BRGM report 82SGN656CSC: 76 pp.

Réhault JP, Boillot G, Mauffret A. 1984. The western Mediterranean basin geological evolution. Marine Geology 55: 447-477.

Reille M, Gamisans J, De Beaulieu J-L, Andrieu V. 1997. The late-glacial at Lac de Creno (Corsica, France): a key site in the western Mediterranean Basin. New Phytologist 135: 547-559.

Reille M, Gamisans J, Andrieu-Ponel V, De Beaulieu J-L. 1999. The Holocene at Lac de Creno, Corsica, France : a key site for the whole island. New Phytologist 141: 291-307.

Riebe CS, Kirchner JW, Granger D, Finkel R. 2000. Erosional equilibrium and disequilibrium in the Sierra Nevada, inferred from cosmogenic ${ }^{26} \mathrm{Al}$ and ${ }^{10} \mathrm{Be}$ in alluvial sediment. Geology 28: 803806.

Roca E., Sans M, Cabrera L, Marzo M. 1999. Oligocene to Middle Miocene evolution of the central Catalan margin (northwestern Mediterranean). Tectonophysics 315: 209-229.

Roering JJ, Kirchner W, Dietrich WE. 1999. Evidence for nonlinear, diffusive sediment transport on hillslopes and implications for landscape morphology. Water Resour. Res. 35: 853-870.

Roering JJ, Kirchner W, Dietrich WE. 2001. Hillslope evolution by nonlinear, slope-dependent transport: steady state morphology and equilibrium adjustment timescales. J. Geophys. Res. 106: 16499-16513.

Roller S, Wittmann H, Kastowski M, Hinderer M. 2012. Erosion of the Rwenzori Mountains, East African Rift, from in-situ produced cosmogenic ${ }^{10} \mathrm{Be}$. J. Geophys. Res. 117: F03003.

Savi S, Norton KP, Picotti V, Akçar N, Delunel R, Brardinoni F, Kubik P, Schlunegger F. 2014. Quantifying sediment supply at the end of the last glaciation: Dynamic reconstruction of an alpine debris-flow fan. Geological Society of America Bulletin 126 (5-6): 773-790

Schlunegger F, Norton KP, Zeilinger G. 2011. Climatic Forcing on Channel Profiles in the Eastern Cordillera of the Coroico Region, Bolivia. The Journal of Geology 119 (1): 97 - 107.

Schmidt KM, Montgomery DR. 1995. Limits to relief. Science 270: 617-620. 
Schneider RR, Price B, Müller PJ, Kroon D, Alexander I. 1997. Monsoon related variations in Zaire (Congo) sediment load and influence of fluvial silicate supply on marine productivity in the east equatorial Atlantic during the last 200,000 years. Paleoceanography 12: 463-481.

Serrano O, Allanic C, Magar M. 2013. Synthèse géologique du bassin tertiaire de la plaine orientale corse. Liaison terre-mer entre Nicolao et Solenzara. BRGM report RP62303FR: 181 pp.

Serrat $P$, Ludwig W, Navarro B, Blazi J-L. 2001. Variabilité spatio-temporelle des flux de matières en suspension d'un fleuve côtier méditerranéen: la Têt (France). C. R. Acad. Sci. Paris, Sciences de la terre et des planètes 333: 389-397.

Severinghaus JP, Sowers T, Brook EJ, Alley RB, Bender ML. 1998. Timing of abrupt climate change at the end of the Younger Dryas interval from thermally fractionated gases in polar ice. Nature 391: $141-146$.

Sklar LS, Dietrich WE. 2001. Sediment and rock strength controls on river incision into bedrock. Geology 29(12): 1087-1090.

Small EE, Anderson RS. 1998. Pleistocene relief production in Laramide mountain ranges, western United States. Geology 26: 123-126.

Snyder NP, Whipple KX, Tucker GE, Merrits DJ. 2000. Landscape response to tectonic forcing: Digital elevation model analysis of stream profiles in the Mendocino triple junction region, northern California. Geol. Soc. Am. Bull. 112(8): 1250-1263.

Sømme TO, Piper DJW, Deptuck ME, Helland-Hansen W. 2011. Linking onshore-offshore sediment dispersal in the Golo source-to-sink system (Corsica, France) during late Quaternary. Journal of Sedimentary Research 81(2): 118-137, doi: 10.2110/jsr.2011.11.

Stanford JD, Rohling EJ, Hunter SE, Roberts AP, Rasmussen SO, Bard E, McManus J, Fairbanks RG. 2006. Timing of meltwater pulse $1 \mathrm{a}$ and climate responses to meltwater injections. Paleoceanography 21: doi:10.1029/2006PA001340.

Stock JD, Montgomery DR. 1999. Geologic constraints on bedrock river incision using the stream power law. J. Geophys. Res. 104: 4983-4993.

Stone JO. 2000. Air pressure and cosmogenic isotope production. J. Geophys. Res. 105: 2375323759.

Strahler AN. 1952. Hypsometric (area-altitude) analysis of erosional topography. Geol. Soc. Am. Bull. 63: 1117-1142.

Summerfield MA, Hulton NJ. 1994. Natural controls of fluvial denudation rate in major world drainage basins. J. Geophys. Res. 99: 871-883.

Syvitski JP, Morehead MD. 1999. Estimating river-sediment discharge to the ocean: application to the Eel Margin, northern California. Marine Geology 154: 13-28.

Torres Acosta V, Schildgen TF, Clarke BA, Scherler D, Bookhagen B, Wittmann H, von Blanckenburg F, Strecker M. 2015. Effect of vegetation cover on millennial-scale landscpe denudation in East Africa. Lithosphere doi:10.113/L402.1

Vanacker V, von Blanckenburg F, Govers G, Molina A, Campforts B, Kubik PW. 2015. Transient river response, captured by channel steepness and its concavity. Geomorphology 228: 234-243. 
Vance D, Bickle M, Ivy-Ochs S, Kubik PW. 2003. Erosion and exhumation in the Himalaya from cosmogenic isotope inventories of river sediment. Earth Planet. Sci. Lett. 206: 273-288.

von Blanckenburg F. 2005. The control mechanisms of erosion and weathering at basin scale from cosmogenic nuclides in river sediment. Earth Planet. Sci. Lett. 237(3-4): 462-479.

Walcott RC, Summerfield MA. 2008. Scale dependence of hypsometric integrals: An analysis of southern African basins. Geomorphology 96: 174-186.

Whipple KX, Tucker GE. 1999. Dynamics of the stream-power river incision model: Implications for height limits of mountain ranges, landscape response timescales, and research needs. $J$. Geophys. Res. 104: 17661-17674.

Whipple KX, E Kirby, Brocklehurst SH. 1999. Geomorphic limits to climate-induced increases in topographic relief. Nature 401: 39-43.

Whipple KX, Hancock GS, Anderson RS. 2000. River incision into bedrock: Mechanics and relative efficacy of plucking, abrasion, and cavitation. Geol. Soc. Am. Bull. 112: 490-503.

Whipple KX. 2004. Bedrock rivers and the geomorphology of active orogens. Ann. Rev. Earth Planet. Sci. 32: 151-185.

Whipple KX. 2009. The influence of climate on the tectonic evolution of mountain belts. Nature Geosciences 2: 97-104.

Wilhelm, F. 1975. Schnee- und Gletscherkunde. De Gruyter, Berlin, New York. 434 pp.

Willenbring JK, Codilean AT, McElroy B. 2013. Earth is (mostly) flat; Apportionment of the flux of continental sediment over millennial time scales. Geology 41: 343-346.

Willett SD. 1999. Orogeny and orography: The effects of erosion on the structure of mountain belts. J. Geophys. Res. 104: 28957-28981.

Willett SD, Brandon MT. 2002. On steady states in mountain belts. Geology 30: 175-178.

Willett SD, Schlunegger F, Picotti V. 2006. Messinian climate change and erosional destruction of the central European Alps. Geology 34(8): 613-616.

Willgoose G. 1994. A physical explanation for an observed-slope-elevation relationship for catchments with declining relief. Water Resour. Res. 30: 151-159.

Wittmann H, von Blanckenburg F, Kruesmann T, Norton KP, Kubik PW. 2007. The relation between rock uplift and denudation from cosmogenic nuclides in river sediment in the central Alps of Switzerland. J. Geophys. Res. 112: F04010.

Wobus C, Whipple KX, Kirby E, Snyder N, Johnson J, Spyropolou K, Crosby B, Sheehan D. 2006. Tectonics from topography: Procedures, promose, and pitfall, In Willett SD, Hovius N, Brandon MT, Fisher DM (eds). Tectonics, Climate, and Landscape Evolution. Geological Society of America, Special Paper 398, Penrose Conference Series: 55-74.

Xoplaki E, González-Rouco JF, Luterbacher J, Wanner H. 2004. Wet season Mediterranean precipitation variability: influence of large-scale dynamics. Clim. Dyn. 23: 63-78.

Yanites BJ, Ehlers TA. 2012. Global climate and tectonic controls on the denudation of glaciated mountains. Earth Planet. Sci. Lett. 325-326: 63-75. 


\section{Figures captions}
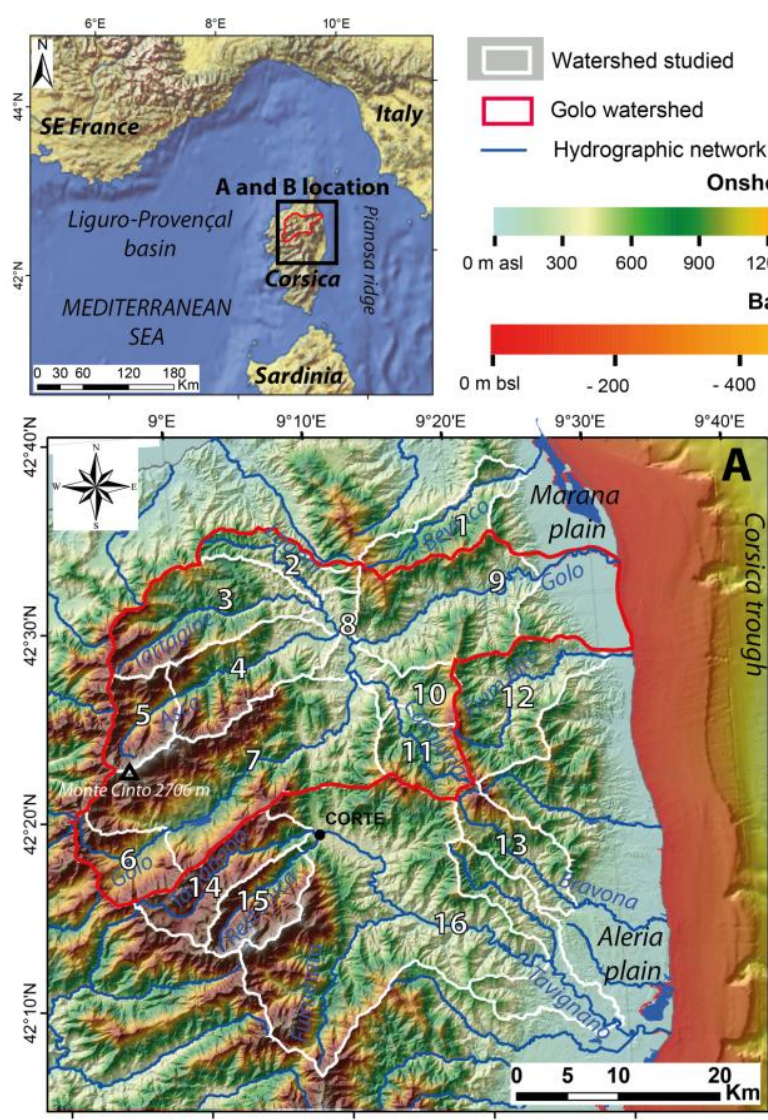

$\Delta \quad$ Main summit

- Main cities

L LGM Glaciers extend

Onshore Elevation

in E, Rossi P, Ferrandini J. 2004.

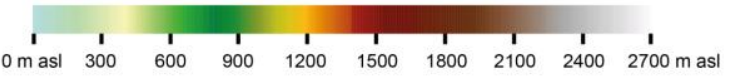
Bathymetry

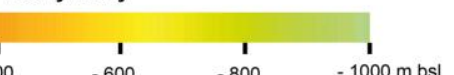

Geology

Hercynian units

Metamorphic basement

Hercynian granites

Permian volcanism

Alpine units

Mesozoic sediments

Mesozoic Ophiolitic complex

Miocene sediments

Plio-Quaternary

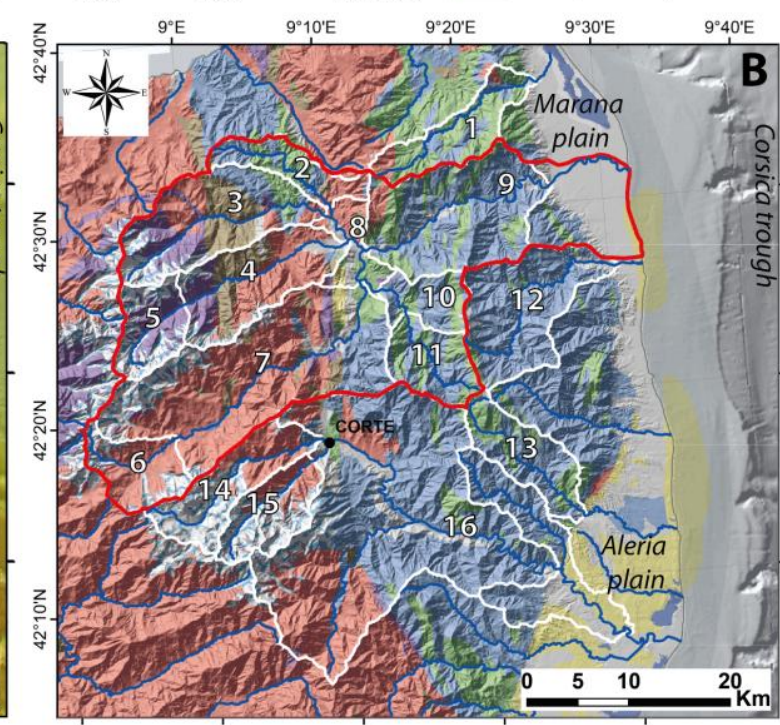

1014

1015 Fig. 1: The geomorphological and geological setting of Corsica. A) Topographic map. B) 1016 Geological map (from Chantraine et al., 1996). LGM glaciers extend from Kuhlemann et al., 1017 (2005b). Names of studied catchments: 1) Bevinco; 2) Lagani; 3) Tartagine; 4) Asco; 5) Asco 1018 glacial-shaped upstream; 6 to 9) Golo with 6) Golo glacial-shaped upstream; 7) Golo 1019 upstream; 8) Golo after confluence with main tributaries; 9) Golo downstream; 10) Casaluna; 11) Casaluna upstream; 12) Fium Alto; 13) Bravona; 14) Tavignano upstream; 15) Restonica; 16) Tavignano downstream. 


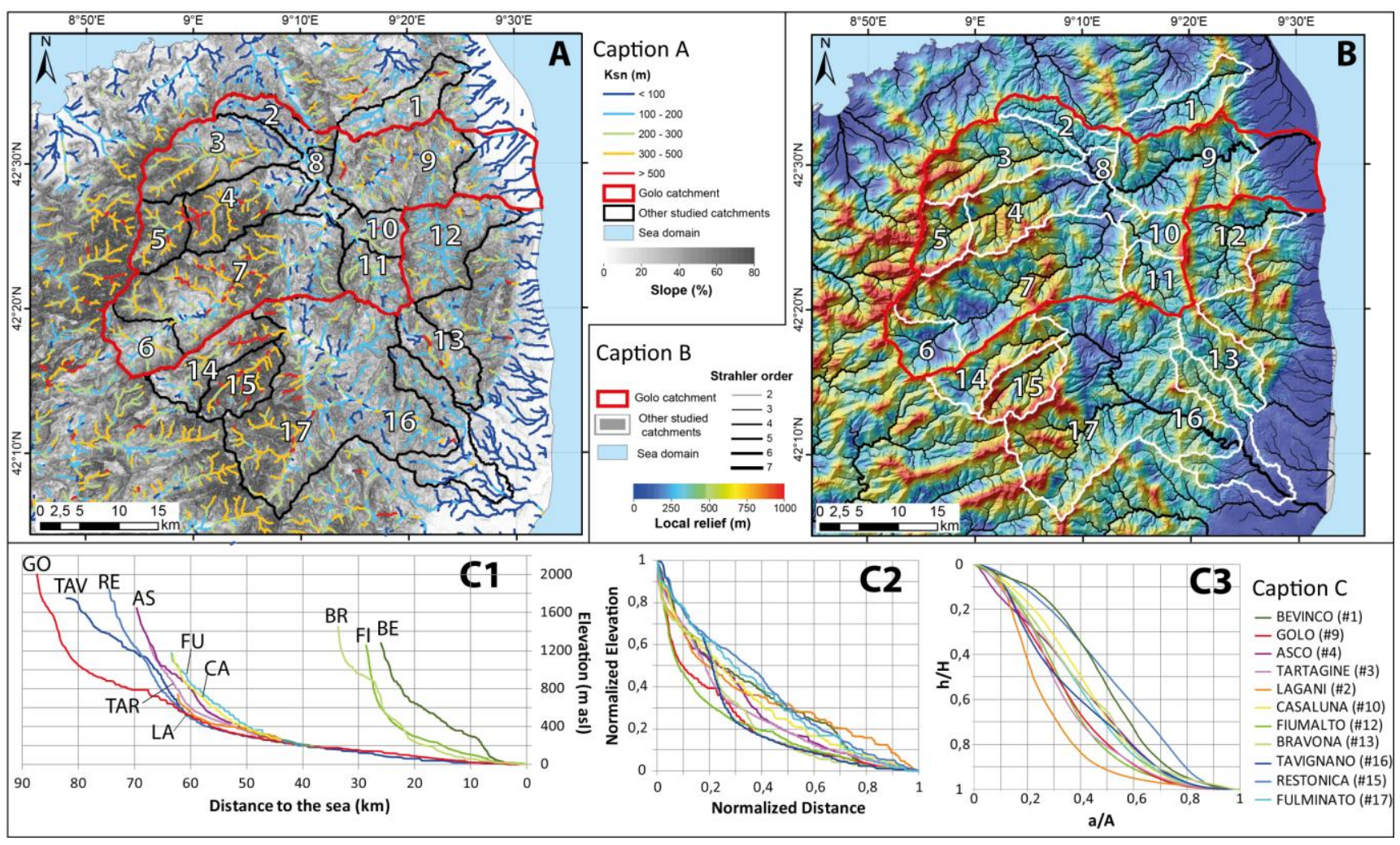

1023 Fig. 2: Geomorphic parameters of the northeastern Corsica: A) Slope map and distribution of 1024 normalized steepness index (Ksn) values of main streams. B) Map of local relief. C) 1025 Longitudinal profiles parameters of the studied Rivers. C1) Longitudinal profiles with respect 1026 to the distance to the coast. C2) Normalized longitudinal profiles. This representation aims to 1027 provide a better comparison of the general shape between profiles. C3) Hypsometric curves 1028 of each studied catchments. See Fig. 1 caption for the catchment number corresponding to 1029 each name. 


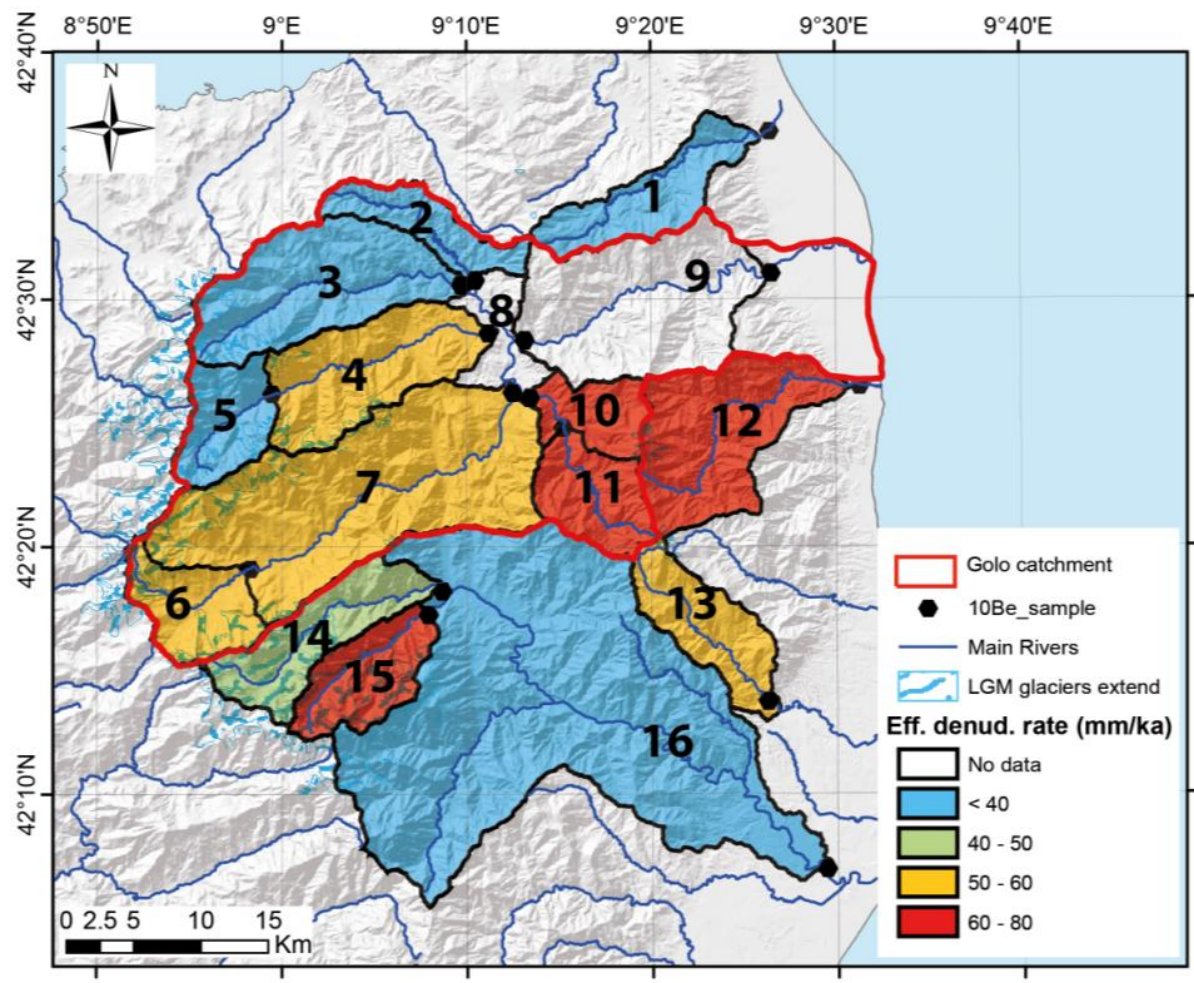

$136.2 \pm 4.8 \mathrm{~mm} \cdot \mathrm{ka}^{-1}$

$233.9 \pm 4.6$ mm.ka ${ }^{-1}$

$333.2 \pm 4.3 \mathrm{~mm} \cdot \mathrm{ka}^{-1}$

$439.3 \pm 4.4 ; 50.9 \pm 7.4$ mm.ka ${ }^{-1}$

$5 \quad 15.4 \pm 1.8 \mathrm{~mm} \cdot \mathrm{ka}^{-1}$

$650.4 \pm 4.8 \mathrm{~mm} \cdot \mathrm{ka}^{-1}$

$751.6 \pm 7.5 ; 52.1 \pm 12.3$ mm.ka- ${ }^{-1}$

$855.1 \pm 8.9$; no value mm.ka-1

$946.5 \pm 9.4$; no value mm.ka-

$1075.5 \pm 10.3 ; 94 \pm 33.8$ mm.ka ${ }^{-1}$

$1161.8 \pm 7.1$ mm.ka ${ }^{-1}$

$1295.3 \pm 11.3$ mm.ka ${ }^{-1}$

$1352 \pm 9$ mm.ka- ${ }^{-1}$

$1446.9 \pm 7.5$ mm.ka ${ }^{-1}$

$1574.1 \pm 8.2$ mm.ka ${ }^{-1}$

$1644.7 \pm 6 ; 39.9 \pm 10.6$ mm.ka ${ }^{-1}$

1031 Fig. 3: Repartition of catchment-wide millennial-scale denudation rates deduced from in situ1032 produced ${ }^{10} \mathrm{Be}$ cosmogenic nuclide concentration on present-day stream sediments. See Fig. 10331 caption for the catchment number corresponding to each name. Denudation rates directly 1034 deduced from ${ }^{10} \mathrm{Be}$ concentrations are in regular form. Effective denudation rates resulting 1035 from the subtraction of nested sub-catchments sediment fluxes are in italic form. 

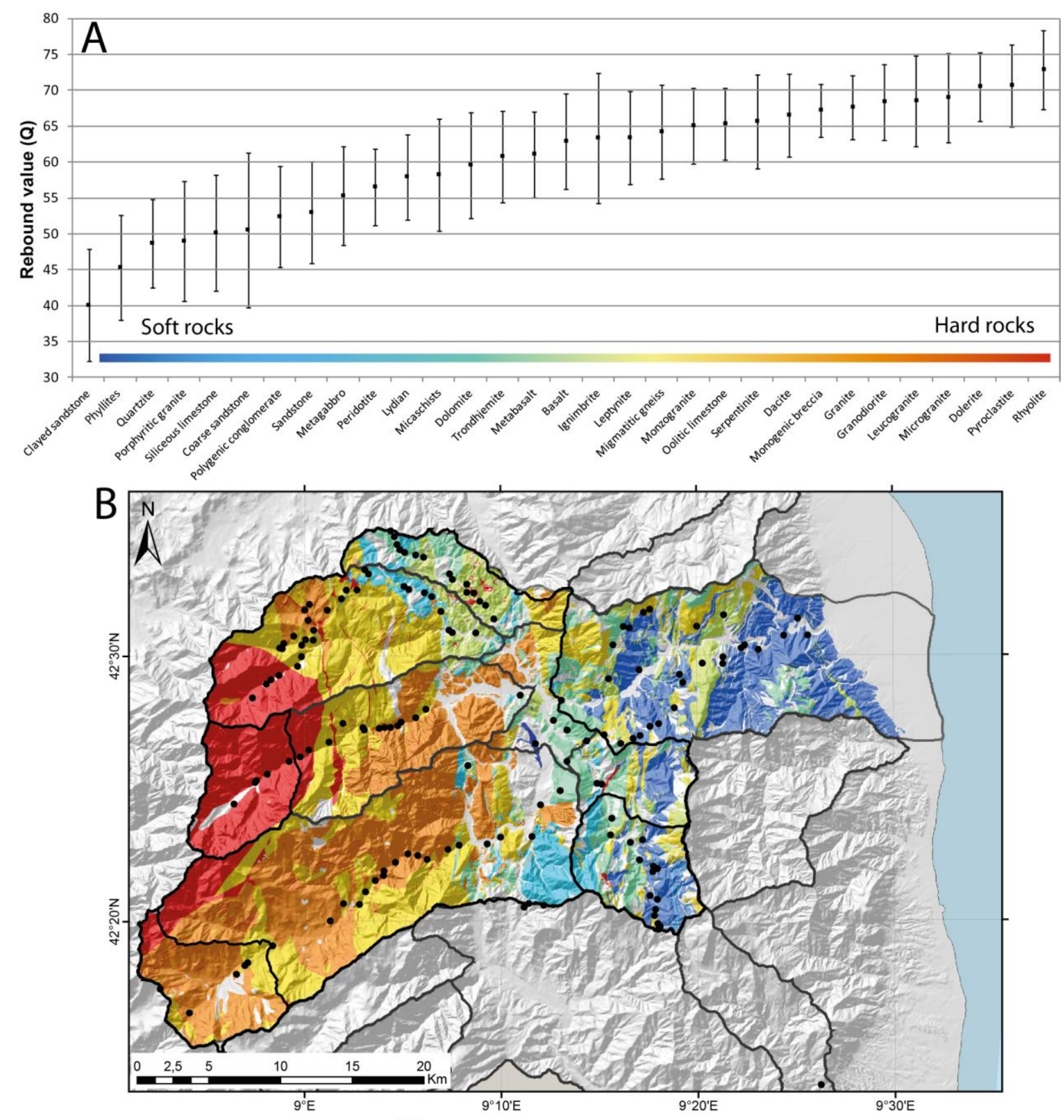

- outcrops measured

$C_{75}^{80}$ Studied watersheds

Rebound value (Q)
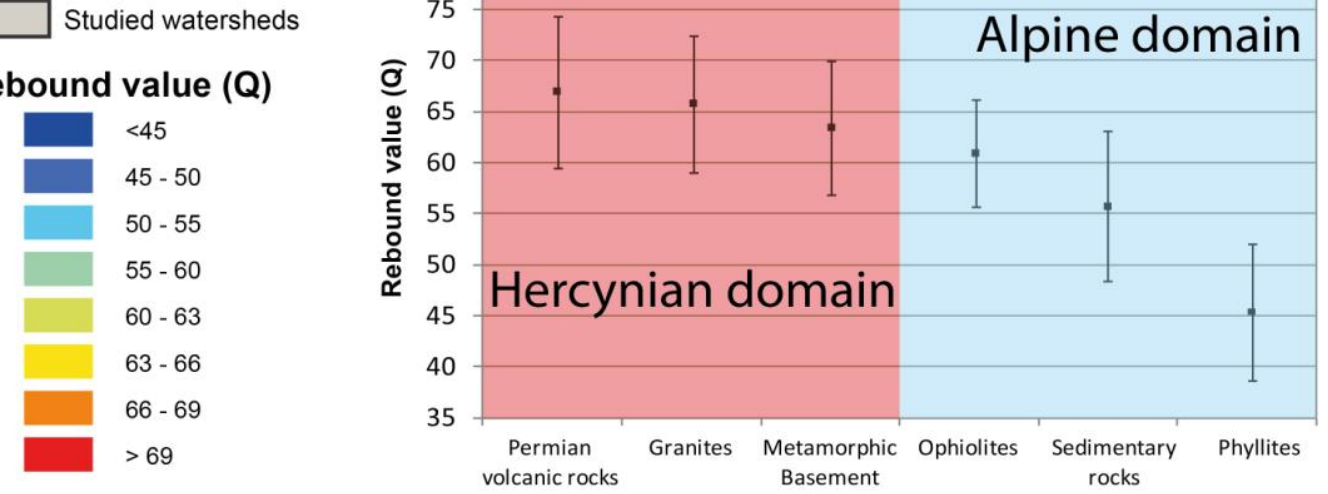

1037 Fig. 4: Schmidt Hammer results and repartition of rock strength in the Golo catchment. A)

Mean rebound value $(\mathrm{Q})$ interpreted from Schmidt Hammer results for each type of rock 
tested. Rock types are arranged from softer to the left to harder to the right. B) Map of rock strength interpolated from mean rebound value (Q) determined for each type of rock and location of in-situ measurements. C) Mean rebound value for each structural unit. The Alpine domain is composed by the three softer structural units which are phyllites, sedimentary rocks, and ophiolites. The Hercynian domain is composed by the three harder structural units, which are metamorphic rocks from basement, granites, and Permian acid volcanism.

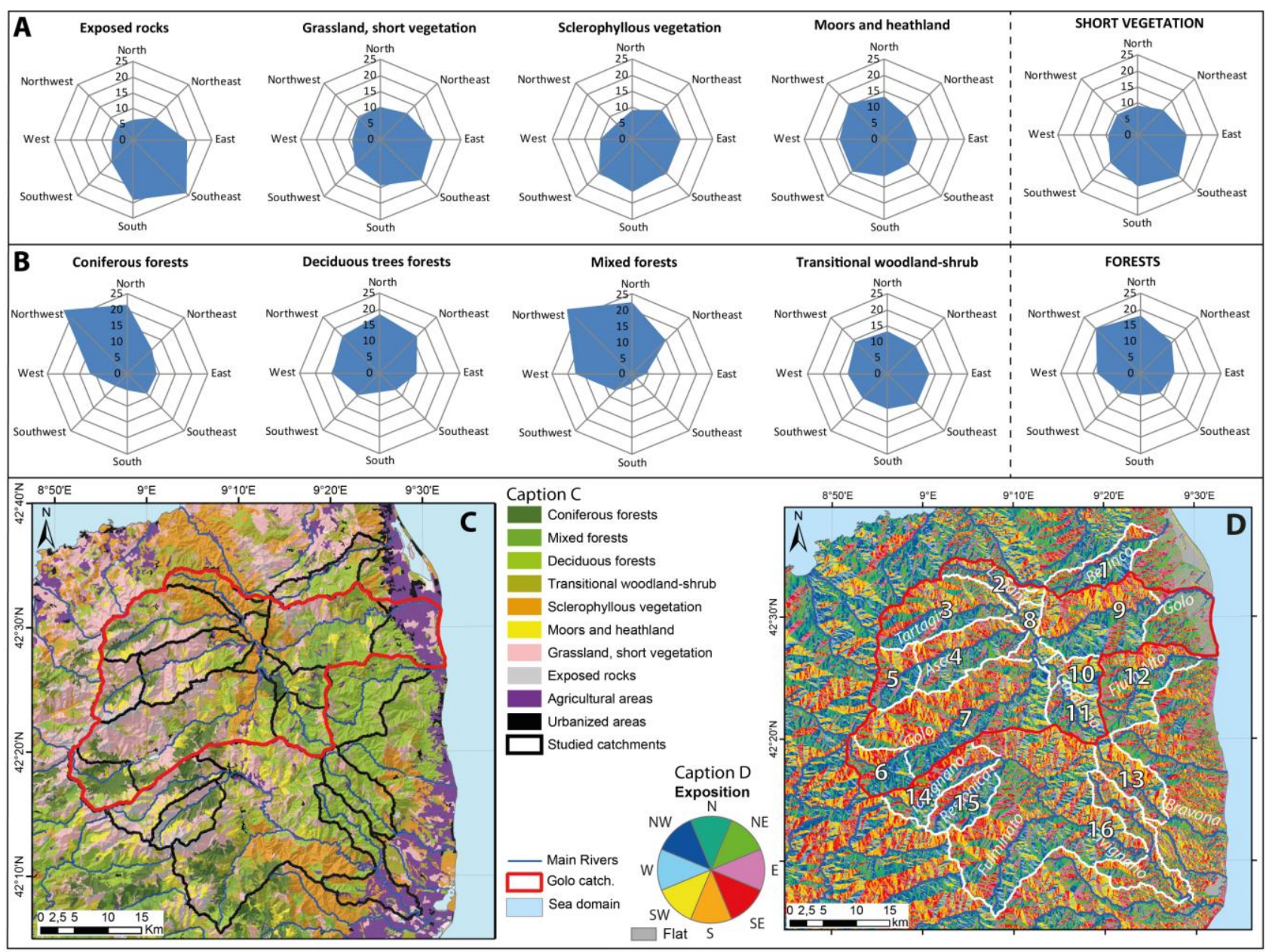

Fig. 5: Landcover and relation with exposition. A) Repartition as a function of the land exposition for each short vegetation type. B) Repartition in function of the land exposition for each elaborated (trees) vegetation types. For A) and B) the graphs on the farther right correspond to compilations for short vegetation and all forest types, respectively. Short vegetation developed preferentially on S- to E-exposed lands whereas forests are preferentially located on $\mathrm{N}$ - to $\mathrm{W}$-exposed lands. C) Repartition of vegetation in the studied area. Data comes from the "Corine Land Cover" European program database (http://www.statistiques.developpement-durable.gouv.fr/donnees-ligne/li/1825.html). D) Map of land exposition direction. The land is considered flat when slope is $<0.1^{\circ}$. 

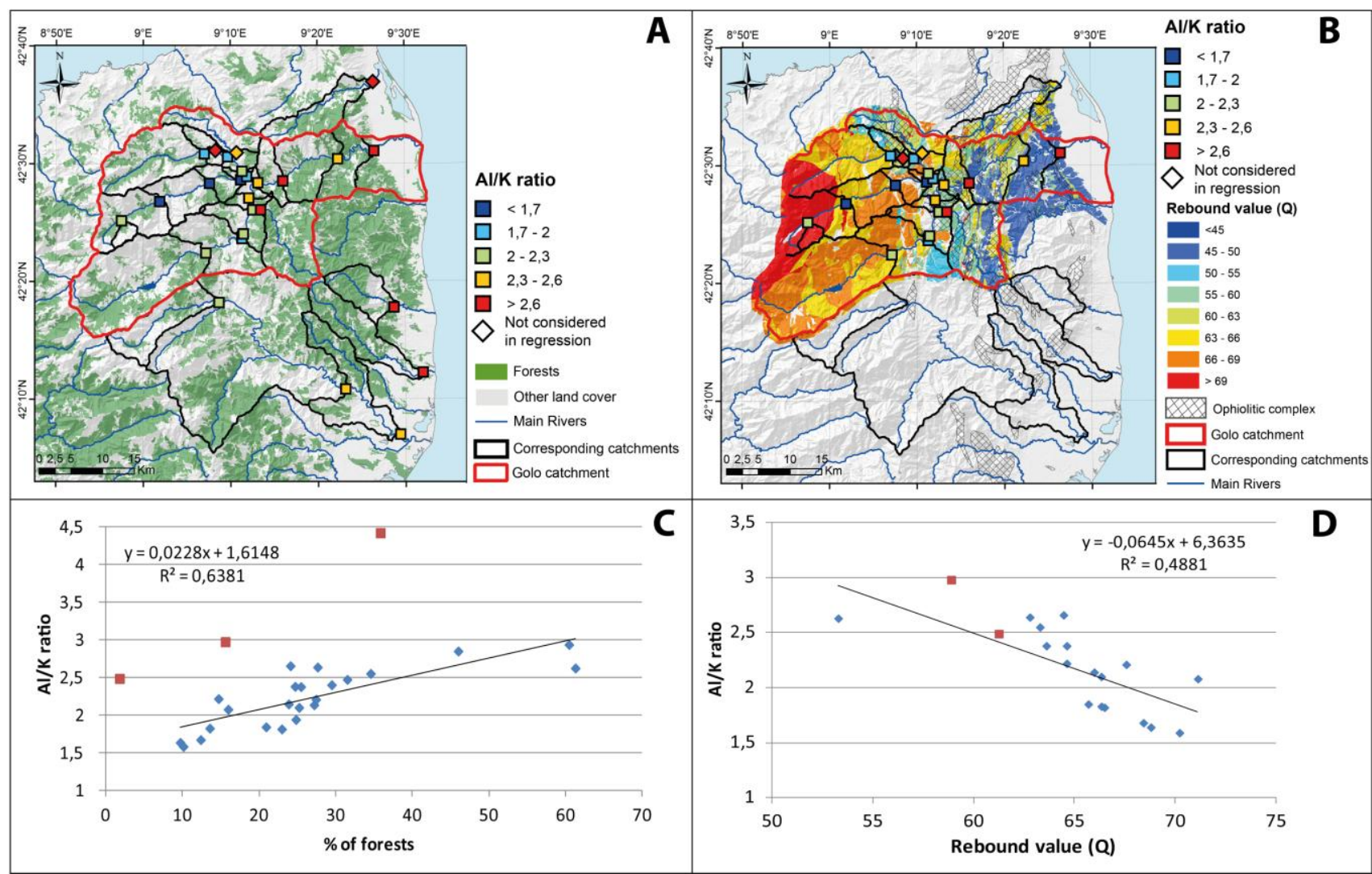

Fig. 6: Al/K measurements: location, results, and comparisons with parameters influencing weathering. A) Location of river sediment samples, corresponding catchments, and $\mathrm{Al} / \mathrm{K}$ value repartition on the vegetal cover map (from "Corine Land Cover" European program database). B) Location of river sediment samples, corresponding catchments, and $\mathrm{Al} / \mathrm{K}$ value repartition on the geological map (from Chantraine et al., 1996). C) Relationship between $\mathrm{Al} / \mathrm{K}$ ratio and percentage of forests in the corresponding catchment. D) Relationship between $\mathrm{Al} / \mathrm{K}$ ratio and mean rebound value $(\mathrm{Q})$ of bedrock in the corresponding catchment. Data only concerns the Golo catchment since we do not have rebound values for the others. For C) and D), red squares correspond to samples located in ophiolitic domain. They are not considered in the linear regression calculation. 

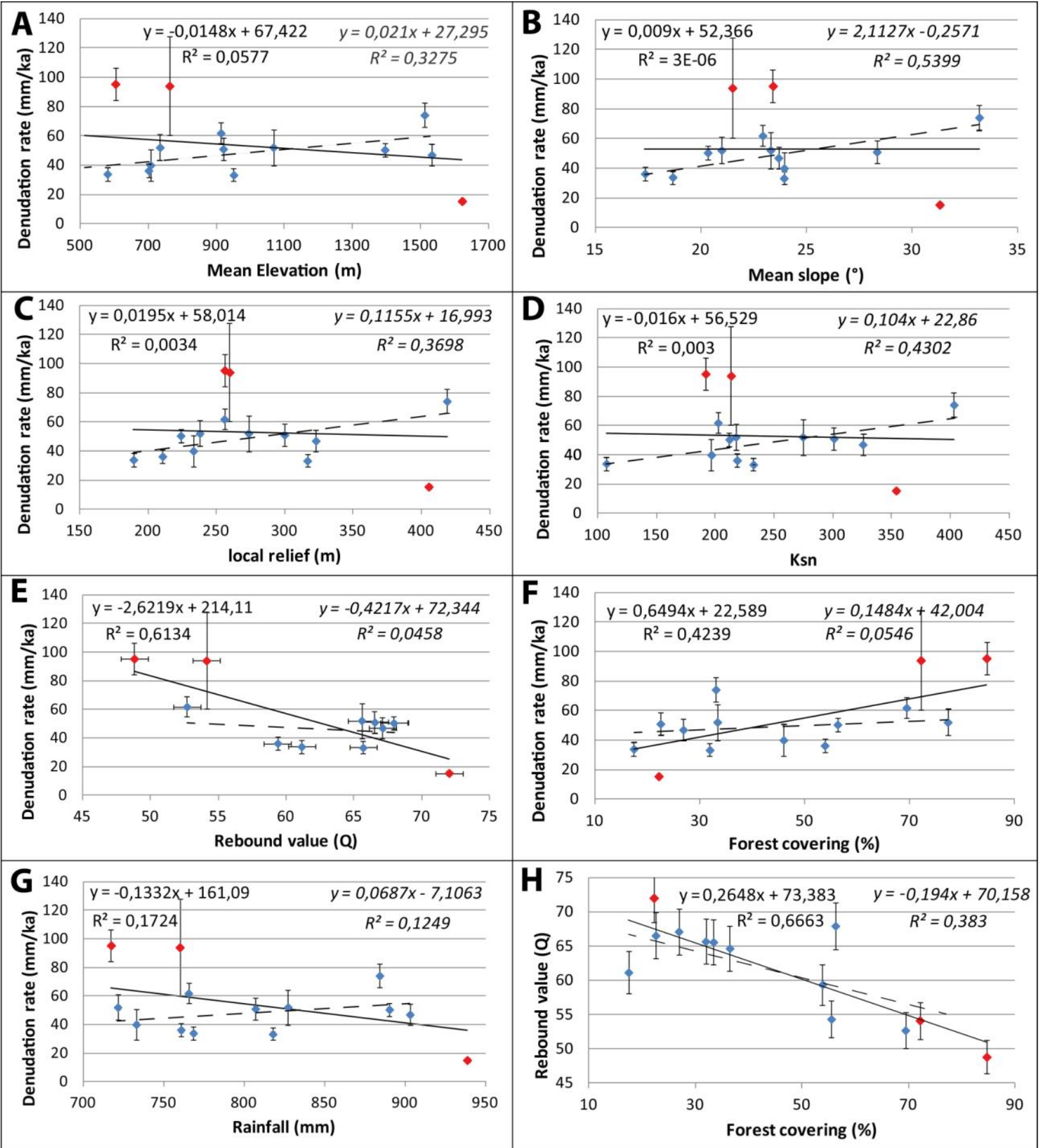

1067 Fig. 7: Comparisons of effective ${ }^{10}$ Be-derived denudation rates with morpho-climatic, lithologic, and land-cover parameters. A) Mean catchment elevation. B) Mean catchment 1069 slope. C) Catchment local relief. D) Mean normalized steepness index (Ksn). E) Rock 1070 strength quantified from mean rebound value (Q). F) Percentage of forests in the catchment 1071 area. G) Annual rainfall. H) Relationship between rock strength and forests. Samples in red 1072 correspond to catchments with extreme values $(5,10,12)$. Linear regressions considering all 1073 samples are represented by the continuous straight line and regular-type equation and $\mathrm{R}^{2}$ 1074 value (left of each graph). Linear regressions concerning only the blue samples are represented by the dashed straight line and italic-type equation and $\mathrm{R}^{2}$ value (right of each 
1076 graph). Rock strength and percentage of forests present at first order a moderate correlation 1077 with denudation rates, which suggests control by weathering processes (regolith 1078 development being more efficient on lands covered by forests and constituted by softer 1079 rocks). Note that forests seem more developed on softer rocks (G). Without catchments 5, 108010,12 to which extreme values of the denudation rate and rock strength are associated, a 1081 moderate correlation with morphometric parameters can be highlighted. 


\section{Table captions:}

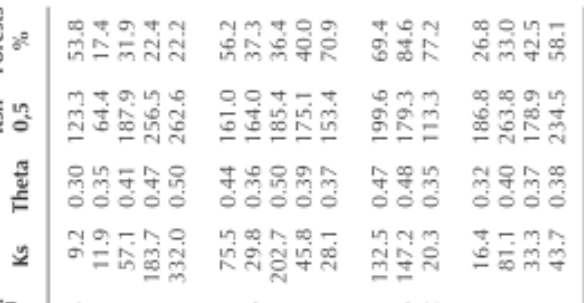

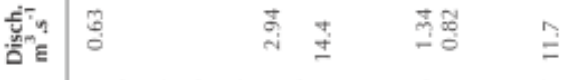

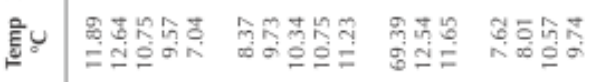

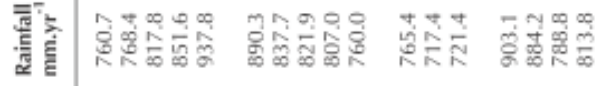

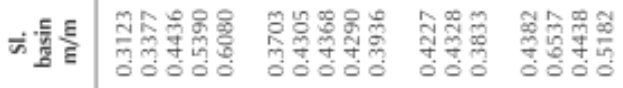

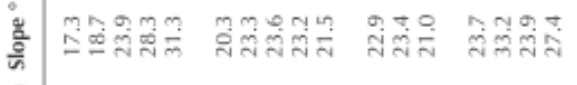

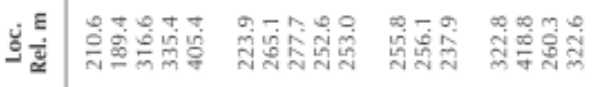

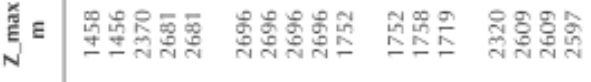

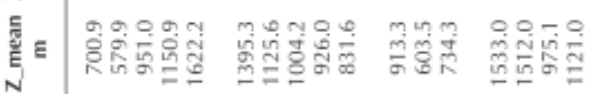

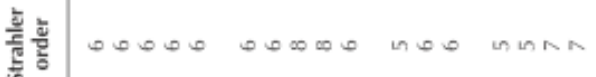

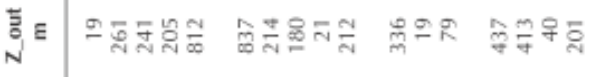

莜

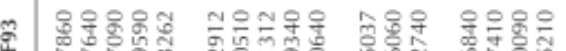

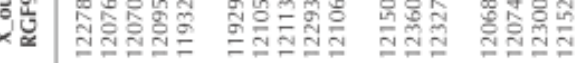

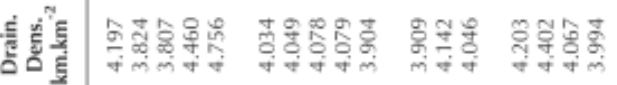

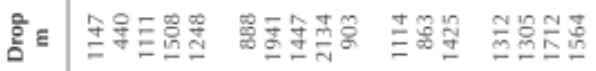

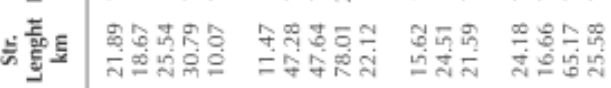

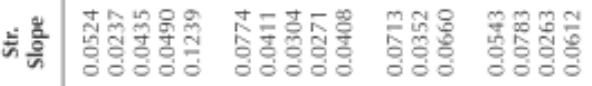

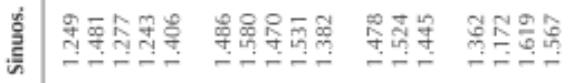

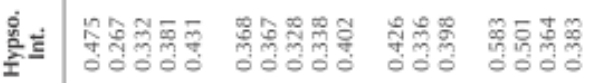

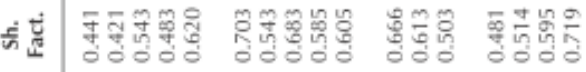

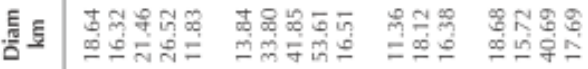

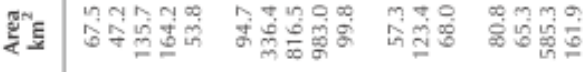

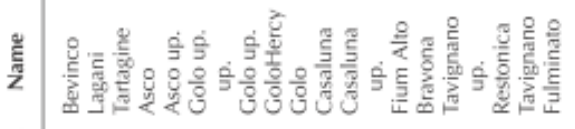



Table1: Geomorphic and climatic parameters of the studied catchments and rivers. Row captions from left to right are: Catchment number; catchment name; drainage area; diameter of the catchment; shape factor; hypsometric integral; mean catchment sinuosity; mean main stream slope; main stream length; gap between the highest and the lowest elevation in the catchment; mean drainage density; latitude of the outlet; longitude of the outlet; elevation of the outlet; Strahler order at the outlet; mean catchment elevation; maximum catchment elevation; local relief; mean catchment slope in degree; mean catchment slope; mean annual rainfall; mean annual temperature; mean annual discharge; steepness index; curvature index; normalized steepness index (curvature is normalized); percentage of forests.

\begin{tabular}{|c|c|c|c|c|c|c|c|c|}
\hline Catch. & River & $\begin{array}{l}\text { Sample } \\
\text { name }\end{array}$ & $\underset{\mathrm{km}^{2}}{\text { Area }}$ & $\begin{array}{l}Y \\
\text { WGS } \\
84\end{array}$ & $\begin{array}{l}\text { X } \\
\text { WGS } \\
84\end{array}$ & Elev. m & $\begin{array}{c}\mathrm{Qz} \\
\text { mass } \mathrm{g}\end{array}$ & $\begin{array}{l}\text { Measure ratios }{ }^{\mathrm{a}} \\
{ }^{10} \mathrm{Be} /{ }^{9} \mathrm{Be}\left(\times 10^{-14}\right)\end{array}$ \\
\hline 1 & Bevinco & BV79 & 67.5 & 9.441 & 42.613 & 19 & 8.323 & $4.957 \pm 0.44$ \\
\hline 2 & Lagani & BV48 & 47.2 & 9.174 & 42.513 & 261 & 20,451 & $13.012 \pm 1.188$ \\
\hline 3 & Tartagine & BV47 & 135.7 & 9.162 & 42.509 & 241 & 7.696 & $6.57 \pm 0.555$ \\
\hline 4 & Asco & BV43 & 164.2 & 9.186 & 42.478 & 205 & 10.248 & $8.668 \pm 0.573$ \\
\hline 5 & Asco & BV33 & 53.8 & 8.992 & 42,436 & 812 & 6.987 & $19.229 \pm 1.366$ \\
\hline 6 & Golo & BV15 & 94.7 & 8.971 & 42.319 & 837 & 14.899 & $11.41 \pm 0.582$ \\
\hline 7 & Golo & BV41b & 336.4 & 9.208 & 42.438 & 214 & 20.917 & $13.389 \pm 1.352$ \\
\hline 8 & Golo & BV63 & 816.5 & 9.219 & 42.473 & 180 & 19,445 & $10.732 \pm 1.256$ \\
\hline 9 & Golo & BV65 & 983.0 & 9.441 & 42.518 & 21 & 7.799 & $5.033 \pm 0.788$ \\
\hline 10 & Casaluna & BV50 & 99.8 & 9.224 & 42.434 & 212 & 18.187 & $6.53 \pm 0.596$ \\
\hline 11 & Casaluna & BV76 & 57.3 & 9.254 & 42.413 & 336 & 17.955 & $8.084 \pm 0.564$ \\
\hline 12 & Fium Alto & BV34 & 123.4 & 9.471 & 42.445 & 19 & 16.432 & $3.914 \pm 0.285$ \\
\hline 13 & Bravona & BV84 & 68.0 & 9.438 & 42.230 & 79 & 15.790 & $7.099 \pm 0.906$ \\
\hline 14 & Tavignano & BV61 & 80.8 & 9.146 & 42.305 & 437 & 19.273 & $17.28 \pm 1.996$ \\
\hline 15 & Restonica & BV62 & 65.3 & 9.131 & 42.289 & 413 & 23.810 & $13.224 \pm 0.871$ \\
\hline 16 & Tavignano & BV36 & 585.3 & 9.488 & 42.116 & 40 & 18.452 & $10.959 \pm 0.981$ \\
\hline
\end{tabular}

Table II. Continued

\begin{tabular}{|c|c|c|c|c|c|c|c|}
\hline Catch. & $\begin{array}{c}\text { Blanks } \\
{ }^{10} \mathrm{Be} /{ }^{9} \mathrm{Be}\left(\times 10^{-14}\right)\end{array}$ & $\begin{array}{c}{ }^{9} \mathrm{Be} \\
\text { carrier } \\
\times 10^{-6} \mathrm{~g}\end{array}$ & $\begin{array}{l}{ }^{10} \mathrm{Be} \text { conc. } \\
10^{3} \text { at.g }\left(\mathrm{SiO}_{2}\right)\end{array}$ & $\begin{array}{l}\text { Prod. rate }{ }^{b} \\
\text { at.g }^{-1} \cdot \mathrm{yr}^{-1}\end{array}$ & Shielding & $\begin{array}{c}\text { Pressure } \\
\text { Mpa }\end{array}$ & $\begin{array}{l}\text { Density } \\
{\text { kg. } \mathrm{m}^{-3}}^{-3}\end{array}$ \\
\hline 1 & $0.306 \pm 0.056$ & 303.5 & $113.5 \pm 10.8$ & $5.92 \pm 0.26$ & 0.849 & 959.1 & 2.7 \\
\hline 2 & $0.305 \pm 0.064$ & 305.0 & $126.2 \pm 11.5$ & $6.03 \pm 0.27$ & 0.961 & 945.7 & 2.7 \\
\hline 3 & $0.222 \pm 0.064$ & 305.6 & $166.9 \pm 14.1$ & $8.11 \pm 0.36$ & 0.940 & 905.1 & 2.7 \\
\hline 4 & $0.222 \pm 0.064$ & 305.9 & $167.4 \pm 11.1$ & $9.78 \pm 0.44$ & 0.945 & 884.1 & 2.7 \\
\hline 5 & $0.306 \pm 0.056$ & 305.5 & $553.6 \pm 40.0$ & $13.18 \pm 0.59$ & 0.930 & 833.5 & 2.7 \\
\hline 6 & $0.306 \pm 0.056$ & 304.5 & $151.9 \pm 8.0$ & $11.49 \pm 0.51$ & 0.957 & 856.9 & 2.7 \\
\hline 7 & $0.305 \pm 0.064$ & 305.1 & $127.1 \pm 12.8$ & $9.71 \pm 0.43$ & 0.962 & 886.5 & 2.7 \\
\hline 8 & $0.305 \pm 0.064$ & 304.8 & $108.7 \pm 12.7$ & $8.8 \pm 0.39$ & 0.956 & 899.6 & 2.7 \\
\hline 9 & $0.305 \pm 0.064$ & 305.0 & $122.1 \pm 19.1$ & $8.31 \pm 0.37$ & 0.957 & 908.2 & 2.7 \\
\hline 10 & $0.305 \pm 0.064$ & 304.8 & $69.1 \pm 6.3$ & $7.5 \pm 0.34$ & 0.967 & 917.7 & 2.7 \\
\hline 11 & $0.306 \pm 0.056$ & 304.3 & $88.2 \pm 6.4$ & $7.9 \pm 0.35$ & 0.958 & 908.6 & 2.7 \\
\hline 12 & $0.306 \pm 0.056$ & 304.7 & $44.8 \pm 3.6$ & $6.01 \pm 0.27$ & 0.931 & 943.4 & 2.7 \\
\hline 13 & $0.306 \pm 0.056$ & 305.3 & $87.9 \pm 11.7$ & $6.54 \pm 0.29$ & 0.902 & 928.8 & 2.7 \\
\hline 14 & $0.222 \pm 0.064$ & 305.3 & $180.2 \pm 20.8$ & $12.81 \pm 0.57$ & 0.953 & 842.8 & 2.7 \\
\hline 15 & $0.222 \pm 0.064$ & 306.6 & $111.5 \pm 7.3$ & $12.48 \pm 0.56$ & 0.936 & 845.7 & 2.7 \\
\hline 16 & $0.305 \pm 0.064$ & 304.8 & $117.1 \pm 10.5$ & $7.61 \pm 0.34$ & 0.936 & 922.2 & 2.7 \\
\hline
\end{tabular}

Table 2: ${ }^{10} \mathrm{Be}$ concentrations and derived denudation rates.

a) The obtained ${ }^{10} \mathrm{Be} /{ }^{9} \mathrm{Be}$ ratios are corrected for procedural blanks and calibrated against the National Institute of Standards and Technology standard reference material 4325 by using an assigned value of $2.79 \pm 0.03 \times 10^{-11}$ and $\mathrm{a}^{10} \mathrm{Be}$ half-life 
of $1.387 \pm 0.012 \times 10^{6}$ years (Korschinek et al., 2010; Chmeleff et al., 2010). Analytical uncertainties (reported as $1 \sigma$ ) include uncertainties associated with AMS counting statistics, chemical blank measurements and AMS internal error (0.5\%). Long-term AMS measurements of procedural blanks yield a background ratio of $3.0 \pm 1.5 \times 10^{-15}$ for ${ }^{10} \mathrm{Be} /{ }^{9} \mathrm{Be}$ (Arnold et al., 2010). The contribution of muons was calculated using the physical parameters evaluated by Braucher et al. (2011).

b) Catchment-averaged production rate is calculated by averaging the values of quartz-producing rocks with a sea-level high-latitude (SLHL) spallation production of $4.03 \pm 0.18$ at g $^{-1} \mathrm{yr}^{-1}$ scaled following Stone's (2000) method. The catchmentaveraged topographic shielding factor is computed from Dunne et al. (1999) using algorithms modified from Balco (2001).

c) Integration time corresponds to the time spent in the equivalent mean attenuation length ( $\sim 60 \mathrm{~cm}$ taking into account a material density of $\left.2.7 \mathrm{~kg} \cdot \mathrm{m}^{-3}\right)(\mathrm{e} . \mathrm{g}$. Lal et al., 1991).

d) Maximum ice cover in percentage considering the maximum integration period computed using the Krumrai (2009) maps of the Würmian ice extent in Corsica.

e) Effective denudation rates obtained subtracting the sediment fluxes from subbasins nested in the parent basins and lacking the sub-catchment part overlapping, as described by Granger et al. (1996) and Portenga et al. (2015).

f) Environmental parameters are computed to be compared to effective denudation rates, i.e. without overlapping between catchments. 


\begin{tabular}{llrlrrr} 
ID & Latitude & Longitude & River name & \% forest & Al/K & Q Schmidt \\
\hline $\mathbf{6 6}$ & 42.374 & 9.119 & Golo & 27.4 & 2.21 & 67.57 \\
$\mathbf{6 8}$ & 42.401 & 9.191 & Golo & 25.2 & 2.10 & 66.33 \\
$\mathbf{4 1}$ & 42.435 & 9.209 & Golo & 27.2 & 2.14 & 65.98 \\
$\mathbf{4 2}$ & 42.451 & 9.202 & Golo & 34.5 & 2.55 & 63.29 \\
$\mathbf{6 3}$ & 42.473 & 9.219 & Golo & 24.7 & 2.38 & 64.62 \\
$\mathbf{6 4}$ & 42.476 & 9.267 & Golo & 24.1 & 2.66 & 64.46 \\
$\mathbf{7 8}$ & 42.507 & 9.372 & Golo & 25.5 & 2.38 & 63.61 \\
$\mathbf{6 5}$ & 42.518 & 9.442 & Golo & 27.6 & 2.64 & 62.79 \\
$\mathbf{5 0}$ & 42.435 & 9.224 & Casaluna & 61.3 & 2.63 & 53.29 \\
$\mathbf{4 5}$ & 42.514 & 9.117 & Tartagine & 23.0 & 1.82 & 66.49 \\
$\mathbf{4 7}$ & 42.510 & 9.161 & Tartagine & 20.9 & 1.85 & 65.69 \\
$\mathbf{4 9}$ & 42.489 & 9.189 & Tartagine & 14.7 & 2.22 & 64.62 \\
$\mathbf{6 9}$ & 42.447 & 9.032 & Asco & 10.1 & 1.59 & 70.21 \\
$\mathbf{7 0}$ & 42.473 & 9.126 & Asco & 9.7 & 1.64 & 68.79 \\
$\mathbf{4 3}$ & 42.477 & 9.186 & Asco & 12.4 & 1.68 & 68.42 \\
$\mathbf{4 4}$ & 42.482 & 9.198 & Asco & 13.6 & 1.83 & 66.34 \\
$\mathbf{3 0}$ & 42.420 & 8.958 & Manica & 16.0 & 2.08 & 71.12 \\
$\mathbf{6 7}$ & 42.394 & 9.189 & Tiolata & 24.8 & 1.94 & 54.07 \\
$\mathbf{4 0}$ & 42.297 & 9.479 & Alesani & 60.4 & 2.94 & \\
$\mathbf{3 9}$ & 42.204 & 9.534 & Bravone & 46.0 & 2.85 & \\
$\mathbf{6 1}$ & 42.304 & 9.145 & Tavignano & 23.8 & 2.15 & \\
$\mathbf{3 7}$ & 42.181 & 9.386 & Tavignano & 29.5 & 2.40 & \\
$\mathbf{3 6}$ & 42.117 & 9.490 & Tavignano & 31.5 & 2.48 & \\
$\mathbf{4 8}$ & 42.513 & 9.174 & Lagani & 1.8 & 2.49 & 61.25 \\
$\mathbf{4 6}$ & 42.518 & 9.138 & San Pietro & 15.6 & 2.98 & 58.89 \\
$\mathbf{7 9}$ & 42.613 & 9.441 & Bevinco & 35.8 & 4.42 & \\
& & & & & &
\end{tabular}

1122

1123 Table 3: Location of samples used for the $\mathrm{Al} / \mathrm{K}$ ratios determination. ID is the name of the 1124 sample. Percentages of forest and rebound values (Q) are also reported for each 1125 corresponding catchment. The analytical error associated with the $\mathrm{Al} / \mathrm{K}$ ratio is lower than $1126 \quad 0.05 \%(2 \sigma)$. 